\title{
Transgenic Crops for Biofortification
}

\author{
Kauser Abdulla Malik* and Asma Maqbool \\ Kauser Abdulla Malik (KAM)-School of Life Sciences, Forman Christian College (A Chartered University), Lahore, Pakistan
}

Global food security concerns impact greatly on the United Nation's Sustainable Development Goals, which are heavily focused on eradicating hunger by 2030. The Global Food Security Index of 2019 has reported that $88 \%$ of countries claim their is enough food supply in their countries, but it is a dreadful reality that every one in three countries is facing insufficient availability of food supply as per the index, meaning more than $10 \%$ of the population is malnourished. Since nutrition is one of the main factors in maintaining a healthy lifestyle and meeting the requirements of food security, several national nutrition surveys conducted in various countries have provided an avenue for governments to assess malnutrition problems across the population. For example, the National Nutrition Survey carried out in 2011 in Pakistan indicated that more than 50\%

OPEN ACCESS

Edited by:

Abdul Wakeel,

University of Agriculture,

Faisalabad, Pakistan

Reviewed by:

Muhammad Ramzan Khan, Quaid-i-Azam University, Pakistan Kathleen L. Hefferon,

Cornell University, United States Faiz Ahmad Joyia,

University of Agriculture,

Faisalabad, Pakistan

*Correspondence:

Kauser Abdulla Malik

kausermalik@fccollege.edu.pk

Specialty section:

This article was submitted to Crop Biology and Sustainability, a section of the journal

Frontiers in Sustainable Food Systems

Received: 10 June 2020 Accepted: 07 September 2020 Published: 03 November 2020

Citation:

Malik KA and Maqbool A (2020) Transgenic Crops for Biofortification. Front. Sustain. Food Syst. 4:571402. doi: 10.3389/fsufs.2020.571402 of the population was food insecure based on the nutritional status of available food. This survey also highlighted the acute deficiency of micronutrients in the diet resulting in several disorders, especially among the female population. In view of these facts, efforts are being made globally to enhance the nutritional value of our agricultural products, especially staple crops, by using several biotechnological approaches.

Keywords: vitamin "A" deficiency, malnutrition, phytate (IHP), biofortifcation, bioavaibility

\section{INTRODUCTION}

Biofortification of crops generally refers to their production with enhanced nutritional value. This can be achieved either by using conventional selective breeding or through genetic engineering. Biofortification differs from fortification because it aims to make plant foods naturally more nutritive rather than adding nutrient supplements to the foods during food processing.

According to an estimate, almost 800 million people all over the world are malnourished, around 98\% of whom are residing in developing countries (Sinha et al., 2019). In addition to this, around 2 billion people globally experience another type of hunger, known as hidden hunger, which is caused by poor intake of essential micronutrients in the everyday diet (Muthayya et al., 2013; Gillespie et al., 2016). A feasible and cost-effective strategy of delivering micronutrients to the populations of developing countries is through biofortified crops. The people of these countries may have restricted access to other micronutrient interventions and diverse diets. Improved varieties can be shared internationally. Biofortified seeds may have an indirect effect in agriculture, as higher concentrations of minerals in seeds provides better protection against different biotic and abiotic stresses, resulting in the enhancement of yield (Welch and Graham, 2004).

In recent years, micronutrient malnutrition has increased exponentially, especially in developing countries. According to the World Health Report, vitamin A, iron, zinc, and iodine deficiencies are the most prevalent deficiencies; these deficiencies contribute substantially to the various health conditions (Allen et al., 2006) that are discussed below. 


\section{MICRONUTRIENT MALNUTRITION ASSOCIATED HEALTH PROBLEMS}

Human bodies are complicated, and they need two types of nutrients for proper functioning and survival: micronutrients and macronutrients. The basis of this division is the quantity of a nutrient that the body needs. Micronutrients are required in small quantities and macronutrients in large.

Micronutrients play an important role in the human body and are involved in mental and physical development (White and Broadley, 2005). Many micronutrients work as cofactors in the proper functioning of different enzymes in the human body and thereby regularize vital functions and metabolic processes. Their deficiencies adversely affecr more than 2 billion individuals, or one in three persons all over the world (Welch and Graham, 2004). These deficiencies occur when the intake and absorption of minerals and vitamins are too poor to sustain good health and development. According to the United Nations World Health Organization, the main challenge in developing countries is not famine, but poor nutrition, and the absence of nutrients essential for the growth and maintenance of important functions. The reasons for malnutrition are inadequate macronutrient consumption, disease, and other factors such as household food security, health services, maternal and childcare factors, and the environment. The problem of malnutrition is further magnified by an increasing world population, which will reach 8 billion by 2030. The bulk of this rise (93\%) will occur in the developing world (Cheema et al., 2008). Micronutrients are not farmed in the body and must be derived from the diet. Crucial micronutrients include iodine, iron, zinc, and vitamins (A, B, and $\mathrm{C}$ ). Although any individual can encounter micronutrient deficiency, in pregnant women and children the chances of developing deficiencies are at a maximum. This is not only due to low dietary intake but also due to the higher physiological demands of pregnancy and childhood development. Almost 38\% of pregnant women and $43 \%$ of pre-school children are suffering from micronutrient deficiencies worldwide. More than $30 \%$ of the world's population is affected by hidden hunger. Deficiencies in micronutrients like iodine, iron, zinc, and vitamin A can have a devastating effect on health (Cheema et al., 2008).

\section{Iron}

In the human body, iron is present in every cell and plays an important role in various cell functions. Being a key component in hemoglobin protein, the most important function of iron is the transportation of oxygen from the lungs to tissues. Moreover, iron is also part of many enzymes that perform vital cell functions (Jimenez et al., 2015). In developing countries, iron deficiency is the most common condition and is the leading cause of anemia, which especially affects young women and children. According to the World Health Organization, over 2 billion people are affected by anemia worldwide, exhibiting symptoms of tiredness and problems in metabolism. Anemia is the primary clinical classification of iron deficiency in half of the population (Benoist et al., 2008). About $30-40 \%$ of preschool children and pregnant women suffer from iron deficiencies in developed countries. The number of people suffering from iron deficiencies in developing countries is even higher (Lucca et al., 2006). Anemia is the most prevalent condition caused by iron deficiency, however, its deficiency may result in other complications such as fatigue, hair loss, pagophagia, pallor, and restless leg syndrome. Severe or untreated iron deficiency may lead to morbidity and death (Dosman et al., 2012; Miller, 2013).

\section{Zinc}

The human body requires a variety of minerals and vitamins to remain healthy. Zinc is one of the essential minerals that the body needs for various biological processes, such as cell division, cell growth, and immune function (Maret and Sandstead, 2006). The body does not require a large amount of zinc, however, unlike other fat-soluble vitamins, the human body does not store zinc for long periods of time. So, there is a constant need for a zinc-enriched diet to prevent its deficiency (Frassinetti et al., 2006). Worldwide, about 1.1 billion people are affected by zinc deficiency due to a poor dietary intake (Kumssa et al., 2015). Zinc deficiency is related to many diseases which include night blindness, weight loss, impaired taste acuity, emotional disturbance, dermatitis, delayed wound healing, poor appetite, alopecia, and poor immunity (Evans, 1986).

\section{lodine}

Iodine is an essential mineral for human health, as it is required for the biosynthesis of the thyroid hormones triiodothyronine (T3) and thyroxine (T4). Globally, more than 2 billion people are affected by an insufficient intake of iodine (Delange, 1994; Zimmermann and Boelaert, 2015). These two hormones, triiodothyronine (T3) and thyroxine (T4), have a vital role in the regulation of metabolism. Iodine deficiency results in a decreased production of these hormones that eventually causes the enlargement of thyroid tissue, a condition known as goiter. As of 2010, more than 187 million individuals are affected by goiter due to iodine deficiency (Greer et al., 1968; Vos et al., 2012). Moreover, iodine deficiency during pregnancy may result in impaired neurodevelopment of the offspring, whereas, during childhood, it affects somatic growth and cognitive functions (Zimmermann and Boelaert, 2015).

\section{Vitamin A}

Vitamin A, a fat-soluble vitamin, is required for a healthy immune system, growth of epithelial cells, eyesight, reproduction, and regulation of genes (Beyer, 2010). Vitamin A deficiency is most prevalent among preschool-aged children, especially in developing countries. It affects almost 100-400 million children throughout the world and every year 20,00050,000 preschool children lose their sight. Among pregnant women, its deficiency also causes night blindness, maternal mortality, and other poor consequences in pregnancy and lactation. Vitamin A is essential for the normal functioning of the visual system, epithelial integrity, immunity, reproduction, and the maintenance of cell growth and function. Many developing countries depend on plant foods to meet their vitamin A requirement (Simpson et al., 2011). 


\section{Vitamin B}

Vitamin $\mathrm{B}$, which is water soluble in nature, has eight forms: vitamin $\mathrm{B} 1, \mathrm{~B} 2, \mathrm{~B} 3, \mathrm{~B} 5, \mathrm{~B} 6, \mathrm{~B} 8, \mathrm{~B} 9$, and $\mathrm{B} 12$. All these forms act as co-factors in different metabolic mechanisms, such as carbohydrate metabolism and protein synthesis. Since each form of vitamin B is involved in different mechanisms, they all have different deficiency symptoms. Vitamin B6, e.g., is necessary for protein metabolism, healthy immune system, the formation of neurotransmitters, and the synthesis of enzymes required during the synthesis of other types of vitamins. However, humans are unable to synthesize it and depend on plants. Unfortunately, the rate of vitamin B6 deficiencies is increasing. Some of the symptoms of vitamin B6 deficiency include skin inflammation, a weak immune system, fatigue, and depression (Bryan et al., 2002).

\section{Vitamin C}

Vitamin C is also a water-soluble vitamin and is mostly obtained from plant sources. It is very well-known for its role in boosting the immune system, especially against allergies due to its antioxidant properties. It also acts as a co-factor in the synthesis of collagen, cholesterol, and certain amino acids (PerezMassot et al., 2013; Maggini et al., 2017). It is also involved in energy metabolism. Its deficiency results in joint pains, bone and connective tissue disorders, poor healing, and a weak immune system (Maggini et al., 2017).

\section{Vitamin E}

Vitamin $\mathrm{E}$ is another fat-soluble vitamin obtained from food sources rich in oil content such as peanuts, sunflower, soybean, and maize. It can be stored in the fat reserves of the body and thus is not required in the daily diet. The recommended dietary intake is $15-22.4 \mathrm{mg}$. It is an antioxidant, helps in the regulation of membrane lipid-packaging, prevents platelet aggregation, helps in eyesight, and is required for the prevention of multiple diseases, such as cancer and cardiovascular diseases. Vitamin E deficiency normally occurs in people with disorders of fat metabolism and can result in muscle weakness, hemolytic anemia, immune system changes, and neurological and ophthalmological disorders (Fitzpatrick et al., 2012; Rizvi et al., 2014).

\section{FACTORS AFFECTING MICRONUTRIENT AVAILABILITY}

Humans depend on plants directly and indirectly for food. Almost all food webs begin with plants, the primary producers. Soil is a reservoir of different types of elements that are essential for the development of a healthy plant. Micronutrients follow a track from the soil to the human body via crop and food. Various critical factors influence the nutrient phytoavailability at each stage, which is discussed below.

\section{Soil and Plant Factors Affecting Micronutrient Phytoavailability}

Plants uptake mineral nutrients from the soil through the roots. The efficiency of nutrient acquisition from the soil to plants is determined by various soil and plant factors. The most important soil factors are its texture, organic matter content, $\mathrm{pH}$, moisture, temperature, soil aeration, farming practice, and interactions with other elements (Alloway, 2009). The composition and chemistry of some soils can make it difficult for plants to uptake nutrients. In certain soils, the nutrients may not be available or may be available in forms that the plants cannot uptake. Nutrient uptake by plants is affected by the amount of root/mycorrhizal surface area (Smethurst and Comerford, 1993; Williams and Yanai, 1996). Some plants change their root structure in nutrientlimited soils, with the most common change being an overall increase in root surface area or elongation of the root system to gain access to new nutrient sources. Some plants can alter the rhizosphere by excreting organic acids or $\mathrm{H}^{+}$ions that increase the availability and uptake of micronutrients (Zhang et al., 2010; Marschner, 2012).

\section{Effect of Diet-Related Factors in Plant Foods That Affect Bioavailability}

Various dietary factors may affect the bioavailability of nutrients from plant foods when they are consumed by humans. These factors include the chemical form of the nutrient in the food, the nature of the food matrix, and interactions between other organic components and nutrients that increase or decrease absorption in the gastrointestinal tract. The most essential factor is the dietary intake, as micronutrient bioavailability depends on the chemical form and amount consumed (Gibson, 2007). The bioavailability of iron can be increased by enhancers like ascorbic acid and can be decreased by inhibitory compounds like polyphenols and phytic acid. The inhibitory compounds form complexes with $\mathrm{Zn}$ and $\mathrm{Fe}$ and restrict uptake by the human body. In addition to this, an individual's age, health, nutrient status, genotype, physiological state, and ethnicity also affect the bioavailability of micronutrients from foods to the human body (Gibson, 2007). The uptake of micronutrients by the human body is often controlled tightly by the status of micronutrients in the individual. During Fe or $\mathrm{Zn}$ deficiency the absorption of $\mathrm{Fe}$ and $\mathrm{Zn}$ is increased (Hallberg and Hulthen, 2000). Micronutrient absorption is decreased in infections and parasitic attacks and, further, they enhance the risk of malnutrition, whereas malnutrition itself makes an individual more vulnerable to infections and parasites (Johnson et al., 2008).

In this scenario, food fortification, a process of adding essential nutrients to food, is the best way to prevent micronutrient malnutrition on a global level without doing substantial changes to food consumption (Allen et al., 2006). In fact, food fortification has been extensively used by industrialized countries to prevent micronutrient malnutrition (Yip, 1994). In addition, developing countries are now also considering or are committed to food fortification programs to fight against micronutrient malnutrition. In Pakistan, several food fortification programs have been initiated, like the Food Fortification Program (FFP) and Global Alliance for Improved Nutrition's (GAIN) programs, whose main goals are to fortify wheat flour and edible oil with micronutrients (Awan et al., 2013). The final task of biofortification is to produce enough 
nutritive food. Currently, several strategies are being used for food fortification.

\section{STRATEGIES FOR FORTIFICATION}

Different strategies for the fortification of food are in use. The most used strategies are shown in Figure $\mathbf{1}$ and discussed below.

\section{Micronutrient Fortification}

Micronutrient fortification is a process of adding one or more micronutrients to foods that are commonly consumed by the general population, such as milk, oil, cereals, and condiments. It is also possible to fortify staple foods such as wheat flour or edible oil (Mass fortification) (Dary and Hainsworth, 2008), or the food which is consumed by a specific population, such as complementary diets for displaced individuals and young children (Targeted fortification). In addition, food manufacturers can also fortify food that is available in the open market. Different micronutrients such as riboflavin, niacin, $\mathrm{Zn}$, and iron were used to fortify wheat products. The supplements are added to the food in the best form to maintain the food's appearance, consistency, and taste. However, for each micronutrient fortification is different. Iron fortification is difficult due to its rapid oxidation. The compounds that have low sensitivity for oxidation are easy to handle in food fortification. This type of fortification is generally designed, mandated, instigated, and regulated by the government. Mass fortification of staple foods is the best option when a large portion of the population is or is becoming deficient in specific micronutrients (Bernier et al., 2008). Mass fortification is extensively employed to prevent clinical and physiological consequences, such as goiter through the iodization of table salt (Zimmermann et al., 2005), neural tube defect by fortifying wheat flour with folic acid, and anemia by fortifying cereals with vitamins and iron (Hurrell, 1997). Food fortification is appealing as there is no need to change the diet of target groups. It is also an effective way of handling micronutrient deficiencies in a larger population. The label must provide information on fortification to the consumers.

\section{Dietary Diversification and Supplementation}

The most sustainable strategy to overcome micronutrient malnutrition is dietary diversification. In this, an attempt is made to consume a variety of different healthy foods, like fruits and vegetables and different grains. Different factors are involved in the success of this approach, such as affordability, dietary habits, accessibility, living style, and bioavailability. In this aspect, awareness in the population can be raised about nutrition by using radio and television programs. Diversity in diet can be enhanced in different ways like improving agricultural production, by producing a good variety of foodstuffs, by using sound food processing and preparation methods, and through multi-sector nutritional advice and training in schools. Moreover, a combination of supplementation (in the form of tablets or packages, either solid or semisolid) and fortification (De-Regil et al., 2013) can be used to improve specific micronutrient deficiencies in the population (Lee et al., 2011).

\section{Biofortification Through Agronomic Practices}

The main source of nutrients for humans is agriculture, specifically for the population of developing countries (Graham et al., 2001; Schneeman, 2001). In most countries, cereals such as wheat, maize, rice, and cassava serve as a primary dietary source. These are not rich sources of several vitamins and micronutrients. Agronomic biofortification can be used to enhance the micronutrient contents of staple crops. This is generally done by using some of the micronutrients as fertilizers to increase their uptake by the plant. These micronutrients are also required by various metabolic processes of the plant.

Amendments to the soil, use of modern tillage technology, and irrigation are some of the agriculture practices implemented so far (Ahmad et al., 2017). The plant must release certain enzymes and organic acids to degrade the organic matter of the soil. It also releases some specific signaling compounds such as flavonoids to attract certain kinds of microbes to aid in nutrient acquisition and provide protection against abiotic/biotic factors (Wood and

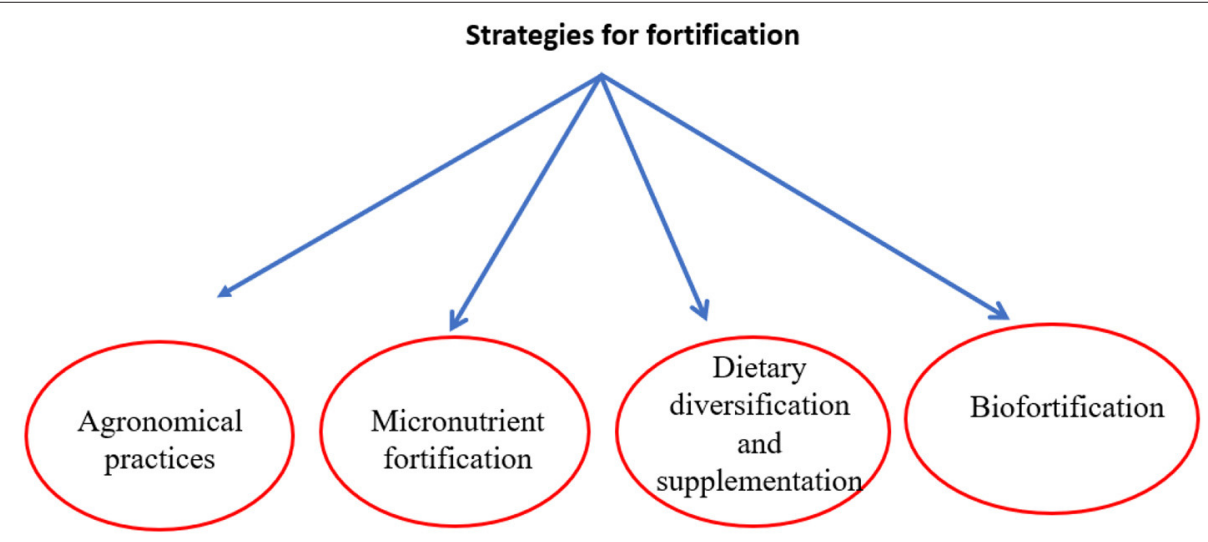

FIGURE 1 | Strategies of food fortification to improve micronutrient content. 
Baudron, 2018; Lyu et al., 2020). The addition of plant growth promoting bacteria (PGPR) to the soil is a popular method as microbes benefit plants by restoring the quality of the soil, help in the assimilation of nutrients, and provide improved water uptake and growth of a plant by releasing hormones, antibiotics, and secondary metabolites (Goicoechea and Antolín, 2017; Backer et al., 2018).

A fast and effective method to fix soil is agronomic biofortification which helps to maintain the fertility of the soil by enriching fertilizers with micro-nutrients for plants in order to enhance the nutritional value of staple crops such as rice, millet, sorghum, wheat, maize, cassava, and sweet potato (De Valença et al., 2017).

Another interesting preparation of soil/land is tillage, which is an extensively used practice by farmers to promote better growth of plants. The timing of soil tillage is an important factor to restore the health of the soil and it must be considered once a year depending on the soil type. Tillage by mechanical means is the fastest system to mix soil with organic matter and inorganic fertilizers in comparison to human-powered tillage methods. The process makes the upper layer of the soil smooth, aids in the release of nutrients by the decomposition of organic matter, creates soil aeration, provides the perfect texture to sow seeds, and removes weeds and hard/compact soil. The combinatorial effect of tillage and use of organic fertilizers and some amount of inorganic fertilizers helps to meet the desired crop nutritional value and fertility of the soil even under unfavorable conditions (Patil et al., 2015). Due to anthropogenic activities, a decline in land for agriculture, and water bodies contamination are making the conditions unfit for plant germination and growth.

Good field nutrient management not only enhances the availability of micronutrients in the crops but also has a high ecological and economic impact. Currently, this approach is practical only for few nutrients, like iodine and zinc. It is not successful with other nutrients, like iron, due to its tendency of rapid excitation and restricted mobility in the phloem. Therefore, the success rate changes with respect to the geographical position. Few micronutrients can be distributed via irrigation water, but the toxic nature of some elements may have a negative impact on the environment. An alternative approach to fortification through agricultural management and food processing is the accumulation of micronutrients directly in cereal seeds using conventional breeding or targeted genetic engineering (Zimmermann and Hurrell, 2002).

\section{Biofortification Through Plant Breeding}

Biofortification is the most sustainable, cost-effective, and promising technology to provide micronutrients to deficient populations on a global level. Biofortification is the process of developing a crop with bioavailable micronutrients in its edible parts. The development of such crops can either be achieved by selective breeding or through modern biotechnological approaches (Garg et al., 2018). Biofortification is more economically sustainable in contrast to other fortification methods because once the crop has developed there will be no further cost for buying fortificants or their addition to foods. In developing countries, many breeding and transgenic programs are underway to enhance staple crops with micronutrients (Nestel et al., 2006; Garg et al., 2018). Selective breeding is one of the most powerful techniques used for biofortification of staple crops, which involves the crossbreeding of existing varieties enriched in micronutrients. Biotechnological approaches are also employed to assist breeding programs, such as molecular marker-assisted section (Collard and Mackill, 2008; Moose and Mumm, 2008) which significantly increases the success of breeding to enhance the nutritional value of crops. However, there are certain limitations in selective breeding, such as low heritability, a lack of genetic diversity for micronutrients, and linkage drag, which makes genetic engineering a more deliberate approach for fortification of staple crops. In the transgenic approach, genes are incorporated into the genome of the crop to produce the micronutrient e.g., golden rice (Paine et al., 2005). Moreover, the crop's genome may manipulate to increase the bioavailability of the micronutrients by reducing the anti-nutrient content. Biofortification efforts are underway in several crops.

\section{Biofortification Through Genetic Engineering}

Techniques of genetic engineering can be used to produce new cultivars with desirable attributes. It utilizes an unlimited pool of genes for the transfer and expression of desirable characteristics from one organism to another, which is evolutionary and taxonomically distinct from one another. Moreover, when a specific micronutrient is not naturally produced in crops, transgenic approaches are the only appropriate option to fortify such crops with that specific nutrient (Perez-Massot et al., 2013). Transgenic crops have been produced by introducing novel genes, overexpressing the genes already present, downregulating the expression of certain genes, or interrupting the synthesis pathway genes of inhibitors.

\section{Iron Biofortified Plants}

Several transgenic strategies have been used to increase the iron content in crops (Table 1) for uptake by humans, which are discussed below.

\section{Insertion of iron-binding protein gene}

The first transgenic approach involves the insertion of an ironbinding protein gene (lactoferrin) under the control of an endosperm specific promoter to achieve $\mathrm{Fe}$ accumulation in the seed which is consumed by humans. For this purpose, plants or crops that store iron in their seeds are targeted. Rice is one such example where many attempts have been made to increase its grain iron content. Rice is favorable for many reasons, such as its low allergenic properties and the absence of toxic compounds that interfere with the expression (Suzuki et al., 2003). Researchers were successful in expressing human lactoferrin in dehusked rice using a strong endosperm specific promoter. It resulted in an increase of $120 \%$ in iron content which was suitable for supplementing infants; however, it was still not enough to meet the daily requirements of adults as one molecule of lactoferrin binds to only two ferric ions (Suzuki et al., 2001). 
TABLE 1 | Transgenic biofortified crops with enhanced iron, zinc, and iodine.

\begin{tabular}{|c|c|c|c|}
\hline Crop & Nutrient & Gene/protein & Reference \\
\hline Arabidopsis & $\mathrm{Fe}$ & $\begin{array}{l}\text { AtNRAMP3 and } \\
\text { AtNRAMP4 }\end{array}$ & Lanquar et al., 2005 \\
\hline Arabidopsis & lodine & $h \mathrm{NIS}$ & Landini et al., 2012 \\
\hline Rice & Fe and $\mathrm{Zn}$ & HVNAS1 & Masuda et al., 2009 \\
\hline Rice & $\mathrm{Fe}$ & OsYSL2 & Ishimaru et al., 2010 \\
\hline Rice & $\mathrm{Zn}$ & OsHMA1 & Lee et al., 2007 \\
\hline $\begin{array}{l}\text { Rice } \\
\text { Rice }\end{array}$ & $\mathrm{Fe}$ & OsIDEF1 & $\begin{array}{l}\text { Kobayashi et al., } 2009 \\
\text { Wirth et al., } 2009\end{array}$ \\
\hline Rice & $\mathrm{Fe}$ & Ferritin & Theil et al., 1997 \\
\hline Rice & $\mathrm{Fe}$ & Lactoferrin & Suzuki et al., 2001 \\
\hline Rice & $\mathrm{Fe}$ and $\mathrm{Zn}$ & fumigates phytase & Lucca et al., 2001 \\
\hline Rice & $\mathrm{Fe}$ & $\begin{array}{l}\text { Metallothionein-like } \\
\text { protein }\end{array}$ & Lucca et al., 2001 \\
\hline Rice & $\mathrm{Fe}$ & OsNAC5 & $\begin{array}{l}\text { Ricachenevsky et al., } \\
2013\end{array}$ \\
\hline Wheat & $\mathrm{Fe}$ & TaVIT2 & Connorton et al., 2017 \\
\hline Wheat & $\mathrm{Fe}$ & GmFerritin & $\begin{array}{l}\text { Borg et al., 2012; } \\
\text { Xiaoyan et al., } 2012\end{array}$ \\
\hline Wheat & $\mathrm{Zn}$ & NAM-B1 & Connorton et al., 2017 \\
\hline Wheat & $\mathrm{Zn}$ and $\mathrm{Fe}$ & OsNAS2 & Singh et al., 2017 \\
\hline Wheat & $\mathrm{Zn}$ and $\mathrm{Fe}$ & phy A & Abid et al., 2017 \\
\hline Wheat & $\mathrm{Zn}$ and $\mathrm{Fe}$ & phy A & $\begin{array}{l}\text { Brinch-Pedersen et al., } \\
2000\end{array}$ \\
\hline Barley & $\mathrm{Fe}$ & AtZIP1 & Ramesh et al., 2004 \\
\hline Maize & $\mathrm{Fe}$ & $\begin{array}{l}\text { Ferritin and } \\
\text { lactoferrin }\end{array}$ & Drakakaki et al., 2005 \\
\hline Pea & $\mathrm{Fe}$ & brz and dgl & $\begin{array}{l}\text { Rogers and Guerinot, } \\
2002\end{array}$ \\
\hline Soybean & $\mathrm{Fe}$ and $\mathrm{Zn}$ & Phytase & Gao et al., 2007 \\
\hline Tobacco & $\mathrm{Fe}$ & AtNAS1 & Douchkov et al., 2005 \\
\hline Tomato & lodine & $\begin{array}{l}\mathrm{HMT}, \mathrm{S} 3 \mathrm{H} \text { and } \\
\text { SAMT }\end{array}$ & Halka et al., 2019 \\
\hline
\end{tabular}

As an alternative, ferritin gene was expressed in rice. Ferritin is known to bind 4,500 ferric ions per molecule (Theil et al., 1997). Iron in the ferritin form is good for human absorption as in the human intestine it is not inhibited by iron absorption inhibitors such as phytate (Theil, 2011). In transgenic rice, a 2 to 3 -fold increase in iron content has been achieved by expressing soybean ferritin under the control of rice seed-storage protein glutelin promoter, GluB-1 (Goto and Yoshihara, 2001). Iron in soybean ferritin is reported to be readily absorbed by the human gut (Lonnerdal, 2003). Some studies reported an increase in iron content of rice plants: a 2-fold increase in dehusked rice using rice glutelin promoter (Lucca et al., 2001) and a 3.7fold increase in Indica cv. IR68144 seeds (Vasconcelos et al., 2003). In addition to rice, ferritin and human lactoferrin genes are reported to increase Fe content in maize grains (Drakakaki et al., 2005), tomato fruits, potato tubers, and lettuce leaves (Goto and Yoshihara, 2001). A factor affecting ferritin over-expression leading to iron accumulation might be soil composition (Vansuyt et al., 2000). Endosperm-specific expression of wheat and soybean ferritin in wheat led to a 1.5 and 1.9 -fold increase in iron content, respectively (Borg et al., 2012; Xiaoyan et al., 2012).

\section{Insertion of an iron-chelator gene}

Nicotianamine (NA) is known to chelate iron and plays a key role in Fe homeostasis and assimilation (Curie et al., 2009). The Ferritin gene co-expressed with the nicotianamine synthase (NAS) gene in rice (Table 1) is reported to show a 6-fold increase in $\mathrm{Fe}$ content, which is higher when compared to the single gene approach (Wirth et al., 2009). In another study, a 7-fold increase in Fe content in transgenic rice seeds was observed by expressing NAS, OsNAS3. Anemic mice fed with these transgenic rice seeds for 4 weeks recovered from iron deficiencies and anemia, while no change was observed in mice fed with nontransgenic rice seeds. Transgenic rice containing HvNAS1 overexpressed by OsActin 1 promoter/35S promoter showed a 5- to 10 -fold increase in endogenous NA levels in the shoots and seeds, leading to 3-fold higher increase in Fe concentration in the T1 seeds (Masuda et al., 2009). Similarly, transgenic tobacco overexpressing nicotianamine synthase (AtNAS1) showed increased Fe levels (Douchkov et al., 2005).

An increase in iron has also been reported in biofortified pearl millet, an amount 2-folds higher than in most modern wheat varieties. An increase in iron absorption by $5-10 \%$ in around 35 million people consuming biofortified pearl millet has been reported (Cercamondi et al., 2013; Sahu, 2017).

\section{Overexpression of the iron reductase gene}

Iron reductase genes are involved in the reduction of ferric [Fe (III)] to ferrous [Fe (II)]. This conversion process is necessary for the incorporation of iron into cellular components (Schroder et al., 2003). Over-expression of Fe (III) reductases in non-graminaceous plants (Morrissey and Guerinot, 2009) can increase the synthesis of phytosiderophores along with the overexpression of YSL proteins. This can help in increasing Fe uptake from iron-deficient soils (Douchkov et al., 2005). Pea (brz and $\mathrm{dgl}$ ) and Arabidopsis (frd3/man1) mutants expressing Fe (III) reductase constitutively accumulate $\mathrm{Fe}$. They also contain high nicotianamine levels (Rogers and Guerinot, 2002).

\section{Over-expression of already present proteins for iron-binding and accumulation}

Leghemoglobin is an example of a protein that is already present in plants and binds to iron in the form of heme, a form that is not affected by anti-nutrients and can make iron readily available for human consumption (Lehtovaara and Ellfolk, 1975; Hallberg, 1981). There is a need to create methods through which the gene for leghemoglobin synthesis would be expressed in edible plant parts. A study on potato tubers expressing the soybean leghemoglobin gene resulted in poor growth of tubers, proving this to be a difficult task (Chaparro-Giraldo et al., 2000).

\section{Insertion of transporter gene}

The amount of iron that accumulates in seeds is dependent on how much of it is absorbed by the plant and transported to the required plant part (Welch, 2002). Mineral ions need to pass 
through the root-soil interface, accumulate in the apoplasm so that these ions are sufficiently collected, and finally transported to the required edible plant parts (Schroeder et al., 2013).

In plants, the $\mathrm{P}_{1 \mathrm{~B}}$-type heavy metal ATPases (HMA) family are important transporters of transition metal ions and are diverse in metal specificity, subcellular localization, and tissue distribution (Li et al., 2015). HMAs are divided into two subgroups on the basis of metal specificity: a zinc $(\mathrm{Zn}) /$ lead $(\mathrm{Pb}) /$ cadmium $(\mathrm{Cd})$ group and sliver (Ag)/copper (Cu) group (Takahashi et al., 2012). Functional studies have demonstrated that $\mathrm{P}_{1 \mathrm{~B}}$-ATPases control the root-shoot transportation of $\mathrm{Zn}$ (Palmgren et al., 2008). In rice, OsHMA1 plays an important role in $\mathrm{Zn}$ transportation as its expression is highly upregulated in shoot tissues under $\mathrm{Zn}$ deficiency. On the other hand, overexpression of OsHMA3 decreased the concentration of $\mathrm{Cd}$ in shoots and grains while increasing the accumulation in roots (Lee et al., 2007).

Another important metal transporter, the HMT (heavy metal transporters) family, encodes for halide ion methyltransferase in roots and leaves and has a key role in the distribution of metal ions in plants (Schwartz et al., 2010). Studies have found that phytochelatin synthases and HMT-1 are required for detoxification of $\mathrm{Cd}$. In another recent transgenic approach, biofortification of iodine in the leaves and fruits of tomato were reported by the expression of HMT, S3H, and SAMT genes (Halka et al., 2019). Therefore, manipulation of HMA and HMT genes can be a promising approach for the biofortification of $\mathrm{Zn}$ and detoxification of $\mathrm{Cd}$.

The OsYSL2 gene in rice was identified from vascular bundles of leaves, seeds, and flowers, indicating its role in Fe transport (Koike et al., 2004). Expression of Fe (II)-NA transporter gene OsYSL2 in rice showed an enhanced iron influx to the seeds (Ishimaru et al., 2010). The rice OsNAC5 gene plays a role in senescence and metal re-mobilization and therefore can be over-expressed for meeting iron requirements (Ricachenevsky et al., 2013). Many vacuolar transporters with altered activity have been shown to increase iron content in seeds: AtNRAMP3 and AtNRAMP4 increase mobilization of vacuolar iron stores in Arabidopsis' early development (Lanquar et al., 2005) and vacuolar iron uptake transporter VIT1 in Arabidopsis (Kim et al., 2006). These vacuolar Fe transporters involved in maintaining Fe homeostasis can be used to produce Fe nutrient-rich seeds by use of biotechnological approaches. Over-expression of Vacuolar Iron Transporter TaVIT2 under the control of an endosperm-specific promoter showed an increase of 2-fold iron content in wheat (Triticum aestivum) (Connorton et al., 2017). Increased Fe levels in barley (Hordeum vulgare) was observed by overexpression of Arabidopsis $\mathrm{Zn} 2 \mathrm{C}$ transporter (AtZIP1) in roots (Ramesh et al., 2004).

The transcription factors (TFs) and Iron deficiency responsive element binding factor (IDEF) are the deficiency induced TFs and key regulator genes in the uptake and utilization of iron $(\mathrm{Fe})$ in plants (Itai et al., 2013). In the transgenic line, the upregulation of OsIDEF1 under Fe stress suggests its transcriptional role in Fe deficiency (Kobayashi et al., 2009). A similar report demonstrated that spatial expression patterns of IDEF1 and IDEF2 during vegetative and reproductive stages are related to Fe deficiency or sufficiency (Kobayashi et al., 2010). In transgenic rice, improved early growth and reduced leaf chlorosis were observed when IDEF1 expressed under the control HvIDS2 promoter. IDEF also positively regulates various Fe transporter genes (e.g., NAS, IRT1, IRO2, DMAS, and YSL). Conversely, RNA interference (RNAi) IDEF mutant lines showed hypersensitivity in Fe deficient conditions (Kobayashi et al., 2009). Thus, IDEF TFs are a potential candidate in terms of biofortification for food crops.

However, when using Fe-transporters the iron influx can be increased but its accumulation in the required plant part is still a concern, therefore, strategies combining the right promoters with the right transporters might be a solution (Drakakaki et al., 2000).

\section{Decreasing Fe-inhibitor/antinutrient}

Phytic acid is considered an antinutrient as it inhibits the absorption of iron and zinc in humans. It is one of the major contributing factors of iron and zinc deficiencies all over the world (Simpson et al., 2011). Enhanced iron and zinc absorption are strongly correlated with a low phytate content in the diet (Bryan et al., 2002; Maggini et al., 2017). Therefore, the reduction of phytate content in staple foods is likely to improve iron and zinc status. Phytases are a special class of phosphatases that catalyze the sequential hydrolysis of phytic acid to produce fewer phosphorylated derivatives of myo-inositol and inorganic phosphate. Some researchers have transformed the phytase gene to cut down the amount of phytate in food to enhance iron and other micronutrients' bioavailability. Rice transgenic plants produced by expressing the phytase gene of Aspergillus fumigatus in rice endosperm resulted in a 130-fold increase in phytase activity in transgenic plants, which was enough to degrade the phytate content (Lucca et al., 2001). Similarly, another study indicated a 50-fold increase in the phytase activity of maize transgenic seeds (Chen et al., 2008). Transgenic wheat plants were developed by expressing the fungal PhyA gene by using two expression cassettes. In one endoplasmic reticulum (E.R), signal sequence was incorporated into one and not into the other. The transgenic plants showed a 4 -fold to a $56 \%$ increase in phytase activity (Brinch-Pedersen et al., 2000). In a study, 2.5-fold higher expression of phytase was observed in transgenic soybean (Gao et al., 2007). A synthetic Phy A gene with an E.R. retention signal sequence, KDEL, resulted in the accumulation of phytase in transgenic seeds and its amount was $2.6 \%$ of the total soluble proteins (Kohli et al., 2006). Phytase transgenic wheat plants were produced by transforming phy A gene. The transgenic plants showed an increment of $18-99 \%$ in phytase activity that resulted in a $12-76 \%$ reduction of phytate in seeds (Abid et al., 2017). Similarly, the overexpression of phytase reduces phytate concentrations in the seeds of several crops including alfalfa, soybean, oilseed rape, rice, wheat, beans, and maize (Chen et al., 2008).

\section{Increasing the synthesis of enhancers that enhance Fe absorption}

Some dietary components have been known to increase iron absorption. These include vitamins such as $\beta$-carotene, ascorbic acid, $\alpha$-tocopherol, and amino acids which are released from proteins during digestion. Ascorbic acid and citric acid are 
known to reduce Fe to a ferrous state and improve absorption in the small intestine. Therefore, transgenic approaches can be used to over-express ascorbic acid in combination with ferritin (Gropper et al., 2005). An increased cysteine content has also been shown to have a good effect on Fe absorption (Layrisse et al., 1984). A higher cysteine content (10-fold) in rice has been achieved by overexpression of a rice metallothionein-like protein. It is similar to metallothionein and contains 12 cysteine residues per mol of protein (Lucca et al., 2001). Enhanced absorption of iron has been observed in golden rice that has elevated levels of $\beta$-carotene (Beyer et al., 2002).

\section{Transgenic Approaches for Improvement of Zinc Content in Plants}

Recent advancements in plant biotechnology enables us to better understand plant metabolisms, which has made it possible to increase micronutrients contents, such as zinc $(\mathrm{Zn})$, iron $(\mathrm{Fe})$, and vitamin $A$, in staple foods to combat mineral malnutrition (Zimmermann and Hurrell, 2002). Zinc deficiency is common worldwide and is associated with various health conditions. Genetic engineering can be used in different ways to improve zinc content in staple foods (Table 1), like the introduction of the specific coding sequencing that codes for zinc-binding protein, overexpression of zinc-storage protein, and/or enhanced expression of specific proteins that are responsible for zinc uptake into plants. Moreover, zinc bioavailability can be increased by introducing a protein that helps to decrease the antinutrient content (Lonnerdal, 2003).

\section{Overexpression of NAS gene family}

Nicotianamine (NA) is a ubiquitous chelator of transition metals (such as $\mathrm{Zn}$ and $\mathrm{Fe}$ ) that is present in higher plants and is responsible for short and long-distance transportation of the metal cations. NA synthase (NAS) enzyme is involved in the biosynthesis of NA by trimerization of S-adenosylmethionine (Takahashi et al., 2003). Genes that encode for NAS are differentially regulated by metal ( $\mathrm{Zn}$ and $\mathrm{Fe}$ ) profiles in a variety of plant species (Table 1), such as Arabidopsis, rice, maize, and barley (Mizuno et al., 2003). Increasing NA concentration in a plant through recombinant DNA technology is mostly carried out by the overexpression of exogenous or endogenous NAS genes. Overexpression of the exogenous HvNAS1 (barley NAS gene) in tobacco and Arabidopsis has led to a several-fold increase in the concentration of zinc, iron, and copper $(\mathrm{Cu})$ in seeds of both plant species (Kim et al., 2005). In another similar study, HvNAS1 overexpression in rice results in greatly enhanced nicotianamine concentration (15-fold more as compared to wild type) which led to a 1.5 and 2.5 -fold increase in zinc and iron concentrations of polished rice grains (Masuda et al., 2009). Constitutive expression of AtNAS1 (Arabidopsis NAS gene) in combination with endosperm-specific expression of ferritin led to an increase in $\mathrm{Fe}$ and $\mathrm{Zn}$ concentration. Furthermore, a high level of $\mathrm{Zn}$ and $\mathrm{Fe}$ in wheat grains was achieved by expressing the OsNAS2 (endogenous NAS gene of rice) and Pv Ferritin (bean ferritin (Singh et al., 2017).

On the other hand, few studies have been reported related to overexpression of the endogenous NAS to increase Planta expression of NA for enhanced metal uptake in plants. The overexpression of the endogenous NAS genes in rice, namely, OsNAS1, OsNAS2, and OsNAS3, resulted in substantial increases in $\mathrm{NA}, \mathrm{Fe}$, and $\mathrm{Zn}$ concentration in the endosperm of all three transgenic populations (Wirth et al., 2009). In a different study, the OsNAS2 overexpressing population had 20 and 2.7-fold more concentration of NA and Zn, respectively, as compared to wildtype. Whereas, OsNAS3 overexpression caused 9-fold more NA, 2.2-fold more $\mathrm{Zn}$, and 2.6-fold more Fe concentration in polished rice grains (Lee et al., 2011).

\section{Overexpression of NAC gene family}

$N A C$ transcription factors play an important role in the senescence of plant species. Senescence is a coordinated phenomenon in which a whole plant or a part of it remobilizes the nutrients to younger tissues or seeds before engaging in programmed cell death. Studies have shown a link between senescence and increased $\mathrm{Zn}$ and Fe remobilization. In wheat, NAM-B1 (a member of NAC transcription factors) has been found to play an essential role in the early onset of senescence, which eventually results in a higher concentration of $\mathrm{Zn}$ in grains (Connorton et al., 2017).

\section{Decreasing the amount of phytic acid}

Phytic acid (also term as phytate) is an inhibitor and antinutrient compound that chelates minerals ( $\mathrm{Zn}$ and $\mathrm{Fe}$ ) that decrease their bioavailability, and hence is the leading cause of mineral malnutrition worldwide (Zhou and Erdman, 1995). Phytic acid makes insoluble complexes when combining with metal ions, especially $\mathrm{Zn}$ and $\mathrm{Fe}$, in the gastrointestinal tract that may not be absorbed or digested in humans because of the lack of intestinal phytase enzyme (Iqbal et al., 1994; Gibson et al., 2010). Phytate can also make complexes with endogenously secreted minerals, e.g., $\mathrm{Zn}$, by reducing their reabsorption into the body. It is best to decrease the content of phytic acid in edible parts of staple crops to increase the absorption of minerals to combat mineral malnutrition. Studies have shown that reducing the content of phytate in the diet is strongly related to increased zinc (Barbro et al., 1985) and iron (Hallberg, 1981) absorption. In phytase, wheat transgenic lines show an increment of $4-115 \%$ in bioavailable zinc (Abid et al., 2017).

\section{Transgenic approaches for improvement of iodine content in plants}

The addition of iodine in table salt is a common strategy to prevent iodine deficiency (Gonzali et al., 2017); however, biofortification of crops with iodine is a more promising strategy to combat mineral malnutrition, as it is more sustainable and cost-effective as compared to other fortification techniques (Garg et al., 2018).

In the last few decades, scientists successfully fortified staple crops with several micronutrients, such as iron (Wirth et al., 2009), zinc (Abid et al., 2017), and folate (Storozhenko et al., 2007). However, to date, no reports of biofortification of iodine in crops using recombinant DNA technology have been published. This is because of the poorly characterized physiology of iodine in plants. According to some hypotheses, 
iodine fluxes across the cell membrane of root cells via anion channels and putative $\mathrm{H}^{+}$/halides transporters. However, such transporters have not yet been molecularly identified. In contrast, the iodine volatilization from over ground parts of plants, such as the root and leaf, are much better characterized in different species. Halide ion methyltransferase (HMT) and halide/thiol methyltransferase (HTMT) activity are found to be responsible for iodine volatilization (Itoh et al., 2009). The only study which employed molecular approaches to enhance the iodine concertation was on transgenic Arabidopsis. In this study, the human sodium-iodide symporter ( $h N I S)$ gene of thyroid glands had overexpressed under the CaMV $35 \mathrm{~S}$ promoter, thus enhanced uptake of iodine was observed. In addition, the $H O L-1$ gene that encodes for HMT enzyme (cause iodine volatilization) was knocked out and a substantial reduction in volatilization in transgenic plant as compared to wild-type was observed (Landini et al., 2012).

\section{Genetically Modified Plants With Improved Vitamin a Profiles \\ Rice}

$\beta$-carotene, a precursor to vitamin $\mathrm{A}$, does not accumulate in the endosperm of rice; however, the $\beta$-carotene precursor, geranylgeranyl pyrophosphate (GGPP), is present in the endosperm. For the first time, the carotene biosynthetic pathway was engineered in carotenoid-lacking and non-photosynthetic tissues (Burkhardt et al., 1997). This was achieved by the transformation of the phytoene synthase gene from daffodils under the control of a seed-specific promoter of glutenin (Gt1) into the genome of rice (japonica variety T309), where the endosperm of the transgenic plants contains phytoene. Later, $\beta$-carotene accumulation in rice endosperm was accomplished by the introduction of three novel genes, namely Erwinia uredovera phytoene desaturase gene (crtI), daffodil phytoene synthase ( $p s y 1)$ gene, and lycopene $\beta$-cyclase (lcy) gene from daffodil (Ye et al., 2000). crtI and $l c y$ genes were expressed under the control of CaMV 35S promoters, while psy1 gene was expressed under the Gt1 promoter, a seed-specific promotor of glutenin. In a different study (Paine et al., 2005), an increment of 23-fold in $\beta$-carotene level was observed by transforming the maize $p s y 1$ gene along with $\operatorname{crt}$ I gene as compared to previously developed golden rice (Ye et al., 2000).

\footnotetext{
Maize

Maize (Zea mays) is an important food crop; however, the $\beta$-carotene content in its kernels is low (Wong et al., 2004). Various reports of transgenic maize with enhanced $\beta$-carotene profiles have been published. One study reports a 34 -fold increase in $\beta$-carotene level as compared to wild-type by overexpressing the bacterial crtI (phytoene desaturase) and crtB (phytoene synthase) gene, driven by the super $g$-zein promoter (Zhu et al., 2008). Maize was genetically engineered by simultaneously targeting three different biosynthesis pathways, $\beta$-carotene, folate, and ascorbate. Transgenic plants contained 169 -folds more $\beta$-carotene, 6-folds more ascorbate, and double the amount of folate as compared to wild-type. This genetically
}

engineered maize can play a crucial role in preventing multiple micronutrient deficiencies (Naqvi et al., 2009).

\section{Wheat}

Globally, wheat (Triticum spp.) is an important cereal crop. Lutein, a non- $\beta$-carotene, is the main carotenoid in wheat (Cunningham and Gantt, 1998). Many transgenic approaches have been reported for the enhancement of the $\beta$-carotene content in the endosperm. One report indicated 10.8-folds higher $\beta$-carotene levels as compared to wild-type, by the transformation of the maize PSY1 and CrtI genes (Cong et al., 2009). Similarly, in another report, an 8-fold increase in $\beta$-carotene level was attained by co-expressing the bacterial $\mathrm{Cr} t \mathrm{~B}$ and CrtI genes (Wang et al., 2014).

\section{Potato}

After rice, wheat, and maize, potato (Solanum tuberosum) is a significant energy source, however, potato tubers contain a minute amount of carotenoids, ranging from 0.5 to $2.5 \mathrm{mg} . \mathrm{g}^{-1}$ of fresh weight (Diretto et al., 2006). The main carotenoids in potato are Violaxanthin, xanthophylls, and lutein however, they lack $\beta$-carotene activities (Lee, 2017). Successful increases in carotenoid contents up to 6.3-folds in transgenic potato was reported (Ducreux et al., 2004). Another report indicated a 14-fold increase in $\beta$-carotene contents by knocking out the lycopene $\varepsilon$-cyclase $(\varepsilon-L C Y)$ gene (Diretto et al., 2006). $\beta$-carotene content has enhanced by knocking out the non-heme $\beta$-carotene hydroxylase $(\mathrm{CHY})$ gene, which converts $\beta$-carotene into zeaxanthin. The transgenic tuber had a reduced level of zeaxanthin, thereby causing a 38 -fold increase in $\beta$-carotene level (Diretto et al., 2007). Vitamin A level has been enhanced in other crops like cassava, mustard, and tomato (Table 2).

\section{Vitamin B Fortified Plants}

Transgenic Arabidopsis were developed that showed a 2-fold increase in vitamin B6 when PDX1 and PDX2 genes of plants were over-expressed in seeds (Chen and Xiong, 2009). A higher increase in vitamin B6 content, along with an increase in the size of aerial organs and tolerance to salt stress, was reported in transgenic Arabidopsis (Raschke et al., 2011) owing to the expression of PDX1 and PDX2 genes under the control of Cam35S promoter (Table 2). Transgenic tomatoes with enhanced fruit-specific expression of GTP cyclohydrolase I have been shown to have enhanced folate content (DelaGarza et al., 2004). Transgenic rice enhanced for vitamin B9 via expressing Arabidopsis thaliana genes of the pterin (Glb-1) and para-aminobenzoate $(G l u B 1)$ branches of the folate biosynthetic pathway have shown an increase of up to 100 -fold and thus may play an important role in combating its deficiency (Storozhenko et al., 2007).

\section{Vitamin C Fortified Plants}

Transgenic crops are being developed with enhanced vitamin C content (Table 2). GDP-l-galactose phosphorylase (GGP or VTC2) gene was used to enhance ascorbate in tomato, strawberry, and potato. Tomato transgenic plants showed a 3 6-fold increase while strawberry transgenic lines showed a 2 fold increase when this gene was expressed under $35 \mathrm{~S}$ promoter. 
TABLE 2 | Transgenic biofortified crops with enhanced vitamin content.

\begin{tabular}{|c|c|c|c|c|}
\hline Vitamin & Crops & Gene used & Target & Reference \\
\hline \multirow[t]{5}{*}{ A } & Cassava & Phytoene synthase gene & Provitamin A & Welsch et al., 2010 \\
\hline & Maize & $\begin{array}{l}\text { Maize PSY and Crtl, } \\
\text { Zmpsy, Pacrtl, Gllycb, Glbch, } \\
\text { ParacrtW }\end{array}$ & $\begin{array}{l}\text { Total carotenoids } \\
\beta \text {-carotene }\end{array}$ & Aluru et al., 2008; Zhu et al., 2008 \\
\hline & Potato & $\begin{array}{l}\text { Crtl, } \\
\text { LCYe, } \\
\text { CHY1, CHY2, } \\
\text { CrtB, Crtl, CrtY } \\
\text { Cauliflower Or } \\
\text { (Orange) gene }\end{array}$ & Total carotenoids $\beta$-carotene & $\begin{array}{l}\text { Ducreux et al., 2004; Diretto et al., 2006, 2007; } \\
\text { Zhu et al., 2008; Li et al., } 2012\end{array}$ \\
\hline & Tomato & Lycopene b-cyclase gene & Precursor b-carotene & $\begin{array}{l}\text { Dela-Garza et al., 2004; Welsch et al., 2007; } \\
\text { Apel and Bock, } 2009\end{array}$ \\
\hline & Wheat & $\begin{array}{l}\text { Maize PSY and } \\
\text { Crtl; CrtB, Crtl }\end{array}$ & $\begin{array}{l}\text { Total carotenoids } \\
\text { ProVitamin A }\end{array}$ & $\begin{array}{l}\text { Cunningham and Gantt, 1998; Wang et al., } \\
2014\end{array}$ \\
\hline \multirow[t]{2}{*}{ B9 } & Tomato & GTP cyclohydrolase I & pteridine synthesis & Dela-Garza et al., 2004 \\
\hline & Rice & (G/b-1 and (G/uB1 & Folate pathway & Storozhenko et al., 2007 \\
\hline \multirow[t]{4}{*}{ C } & Strawberry & $\begin{array}{l}\text { GalUR } \\
\text { GDP-I-galactose phosphorylase }\end{array}$ & $\begin{array}{l}\text { NADPH-dependent D-galacturonate } \\
\text { reductase } \\
\text { Smirnoff-wheeler pathway }\end{array}$ & Agius et al., 2003; Bulley et al., 2012 \\
\hline & Potato & GDP-I-galactose phosphorylase & Smirnoff-wheeler pathway & Bulley et al., 2012 \\
\hline & Corn & dehydroascorbate reductase (dhar) & Smirnoff-wheeler pathway & Naqvi et al., 2009 \\
\hline & Tomato & GDP-I-galactose phosphorylase & Smirnoff-Wheeler pathway & Bulley et al., 2012 \\
\hline \multirow[t]{3}{*}{ E } & Tobacco & HGGT & Tocochromanol pathway & Tanaka et al., 2015 \\
\hline & Arabidopsis & HGGT and HPT & Tocochromanol pathway & Cahoon et al., 2003; Yang et al., 2011 \\
\hline & Corn & HGGT and HPT & Tocochromanol pathway & Dolde and Wang, 2011 \\
\hline
\end{tabular}

Among the potato transgenic lines only one line inreased up to 3-fold (Scholes et al., 2012). Corn was biofortified with vitamin $\mathrm{C}$, vitamin $\mathrm{A}$, and vitamin $\mathrm{B} 9$. To enhance vitamin $\mathrm{C}$ content, rice dehydroascorbate reductase (dhar) was expressed under the control of the barley D-hordein promoter. This transgenic corn showed up to a 6 -fold increase in ascorbate content (Naqvi et al., 2009).

\section{Vitamin E Fortified Plants}

Vitamin E content has been increased in tobacco, corn, and Arabidopsis via the transgenic approach. Overexpression of the genes HGGT and HPT in the tocochromanol pathway increased tocochromanol content up to 5 times in tobacco leaves, up to 15 times in Arabidopsis leaves, and 7-18 times in maize kernels (Dolde and Wang, 2011; Yang et al., 2011; Tanaka et al., 2015).

\section{Potential of Genome Editing Technology}

The use of mega-nucleases, such as zinc-finger nucleases (ZFNs) and Transcription activator-like effector nucleases (TALENs), have changed the gene-editing game. These enzymes consist of DNA binding domains combined to nuclease domains for making DNA breakages at specific positions, making them highly specific compared to old DNA transfer techniques like Agrobacterium-mediated transfer or particle bombardment. These have been used successfully to genetically modify plants such as tobacco, Arabidopsis, rice, wheat, and barley (Jaganathan et al., 2018; Sedeek et al., 2019; Ansari et al., 2020). The designing of these proteins, however, is complex and thus is expensive as well-laborious (Belhaj et al., 2015).

A drawback in using these mega-nucleases, however, can be eliminated using Crispr-Cas9 technology, a more precise, cost-effective, and versatile method. It involves the use of sequence specific guide RNA and PAM motif for the identification of cleavage sites. However, at times off-target cleavage occurs, resulting in undesirable outcomes. Increasing the PAM sequence length has evaded such off-target cleavages (Jaganathan et al., 2018). By modifying the germline cells, Crispr-cas technology has the potential to develop transgenics without involving transformation and tissue culture plants. Similarly, this technology also has the potential to engineer single cells, but regeneration of the single cells is still difficult (Sedeek et al., 2019). Several biofortified transgenic crops, such as rice, wheat, and Arabidopsis, have been developed by using these technologies to prevent micronutrient deficiencies of iron, zinc, vitamin A, and vitamin B1 (Ricroch et al., 2017; Deepa et al., 2018). Mutant lines of Glycine max and Medicago truncatula for the genes of small RNA processing were developed by using CRISPR/Cas9 and TALENs (Curtin et al., 2018; Jha and Warkentin, 2020). Similarly, in cowpeas, symbiotic nitrogen fixation gene activation was disrupted successfully 
by using CRISPR/Cas9 (Ji et al., 2019; Jha and Warkentin, 2020). In rice, calli $\beta$-carotene level is enhanced by targeting the Osor gene through CRISPR/Cas9 (Endo et al., 2019). Recently, marker-free rice with an increased level of carotenoids was developed by inserting a $5.2 \mathrm{~kb}$ cassette of carotenoid biosynthesis by using the CRISPR-Cas9-based method (Dong et al., 2020).

With further advancements, these genome editing technologies have the potential of developing all types of transgenics with very little time and cost.

\section{CONCLUSION}

It is evident that biofortification holds great promise for improving the nutritive value of major crops. By the use of recombinant DNA technology, the bioavailability of several essential micronutrients and vitamins could be increased. External fortification of these nutrients has limited value, as such fortified food materials are generally available to the urban population. In the developing world, the majority of the population is rural and fortified food is neither accessible nor affordable for them. Biofortification, by providing the technology through seeds of the major staple crops, can be of great advantage in meeting the nutritive requirements of poor populations at an affordable cost.

However, one of the major concerns is that very few biofortified transgenic crops have been commercialized for general cultivation. Even the well-known Golden Rice, biofortified with Vitamin A, has been approved by FDA only

\section{REFERENCES}

Abid, N., Khatoon, A., Maqbool, A., Irfan, M., Bashir, A., Asif, I., et al. (2017). Transgenic expression of phytase in wheat endosperm increases bioavailability of iron and zinc in grains. Transgenic Res. 26, 109-122. doi: 10.1007/s11248-016-9983-Z

Agius, F., González-Lamothe, R., Caballero, J. L., Muñoz-Blanco, J., Botella, M. A., and Valpuesta, V. (2003). Engineering increased vitamin C levels in plants by overexpression of a D-galacturonic acid reductase. Nat. Biotechnol. 21, 177-181. doi: $10.1038 / \mathrm{nbt} 777$

Ahmad, S., Israr, M., and Rehman, M. U. (2017). Agronomic practices and adaptive strategies of the farmers to climate change in central Pakhtunkhwa, Pakistan. Pesqui. Agropecu. Bras. 6, 1132-1150. doi: 10.19045/bspab.2017. 600122

Allen, L. H., De Benoist, B., Dary, O., Hurrell, R., and Organization, W. H. (2006). Guidelines on Food Fortification with Micronutrients. Geneva: World Health Organization.

Alloway, B. (2009). Soil factors associated with zinc deficiency in crops and humans. Environ. Geochem. Health. 31, 537-548. doi: 10.1007/s10653-009-9255-4

Aluru, M., Xu, Y., Guo, R., Wang, Z., Li, S., White, W., et al. (2008). Generation of transgenic maize with enhanced provitamin a content. J. Exp. Bot. 59, 3551-3562. doi: 10.1093/jxb/ern212

Ansari, W. A., Chandanshive, S. U., Bhatt, V., Nadaf, A. H. B., Vats, S., Katara, J. L., et al. (2020). Genome editing in cereals: approaches, applications and challenges. Int. J. Mol. Sci. 21:4040. doi: 10.3390/ijms21114040

Apel, W., and Bock, R. (2009). Enhancement of carotenoid biosynthesis in transplastomic tomatoes by induced lycopene-to-provitamin a conversion. Plant Physiol. 151, 59-66. doi: 10.1104/pp.109.140533 after more than a decade spent on meeting the regulatory requirements. Last year, on December 18, 2019, the Philippines approved Golden Rice for direct use as food and feed, or processing after rigorous biosafety assessments by the Philippine Department of Agriculture-Bureau of Plant Industry. To benefit from this technology, the regulators have to revisit different protocols so that all unnecessary regulations based on "precautionary" principles could be removed. Such an approach will greatly benefit society at large and will be instrumental in achieving food security.

\section{AUTHOR CONTRIBUTIONS}

$\mathrm{KM}$ and AM collected the literature. AM wrote the first draft. KM edited and finalized the manuscript. Both authors contributed to the article and approved the submitted version.

\section{FUNDING}

The funding for research in the related areas was obtained from the Punjab Agricultural Research Board for the project on the Development of Transgenic Wheat for increased bioavailability of iron and Zinc. Project No. 188. This grant ended about 3 years back.

\section{ACKNOWLEDGMENTS}

The authors wish to thank the Punjab Agricultural Research Board (PARB) for supporting a project on Biofortified Wheat for increased bioavailability of $\mathrm{Fe}$ and $\mathrm{Zn}$.

Awan, J. A., Anjum, F. M., and Huma, N. (2013). "Food fortification programmes in Pakistan," in Handbook of Food Fortification and Health. eds V. R. Preedy, R. Srirajaskanthan, and V. B. Patel (New York, NY: Springer), 347-360.

Backer, R., Rokem, J. S., Ilangumaran, G., Lamont, J., Praslickova, D., Ricci, E., et al. (2018). Plant growth-promoting rhizobacteria: context, mechanisms of action, and roadmap to commercialization of biostimulants for sustainable agriculture. Front. Plant Sci. 9:1473. doi: 10.3389/fpls.2018.01473

Barbro, N., Brittmarie, S., and Cederblad, A. (1985). Reduction of the phytate content of bran by leavening in bread and its effect on zinc absorption in man. Br. J. Nutr. 53, 47-53. doi: 10.1079/BJN19850009

Belhaj, K., Chaparro-Garcia, A., Kamoun, S., Patron, N. J., and Nekrasov, V. (2015). Editing plant genomes with CRISPR/Cas9. Curr. Opin. Biotech. 32, 76-84. doi: 10.1016/j.copbio.2014.11.007

Benoist, B., McLean, E., Egll, I., and Cogswell, M. (2008). Worldwide Prevalence of Anaemia 1993-2005, WHO Global Database on Anaemia. Geneva: World Health Organization.

Bernier, J., Atlin, G. N., Serraj, R., Kumar, A., and Spaner, D. (2008). Breeding upland rice for drought resistance. J. Sci. Food Agric. 88, 927-939. doi: $10.1002 /$ jsfa. 3153

Beyer, P. (2010). Golden rice and golden crops for human nutrition. Nat. Biotechnol. 27, 478-481. doi: 10.1016/j.nbt.2010.05.010

Beyer, P., Al-Babili, S., Ye, X., Lucca, P., Schaub, P., and Welsch, R., et al. (2002). Golden rice: Introducing the $\beta$-carotene biosynthesis pathway into rice endosperm by genetic engineering to defeat vitamin A deficiency. J. Nutr. 132, 506S-510S. doi: 10.1093/jn/132.3.506S

Borg, S., Brinch-Pedersen, H., Tauris, B., Madsen, L. H., Darbani, B., and Noeparvar, S., et al. (2012). Wheat ferritins: improving the iron content of the wheat grain. J. Cereal Sci. 56, 204-213. doi: 10.1016/j.jcs.2012. 03.005 
Brinch-Pedersen, H., Olesen, A., Rasmussen, S. K., and Holm, P. B. (2000). Generation of transgenic wheat (Triticum aestivum L.) for constitutive accumulation of an Aspergillus phytase. Mol. Breed. 6, 195-206. doi: 10.1023/A:1009690730620

Bryan, J., Calvaresi, E., and Hughes, D. (2002). Short-term folate, vitamin B12 or vitamin B-6 supplementation slightly affects memory performance but not mood in women of various ages. J. Nutr. 132, 1345-1356. doi: $10.1093 /$ jn/132.6.1345

Bulley, S., Wright, M., Rommens, C., Yan, H., Rassam, M., Lin-Wang, K., et al. (2012). Enhancing ascorbate in fruits and tubers through over-expression of the l-galactose pathway gene GDP-l-galactose phosphorylase. Plant Biotechnol. J. 10, 390-397. doi: 10.1111/j.1467-7652.2011.00668.x

Burkhardt, P. K., Beyer, P., Wünn, J., Klöti, A., Armstrong, G. A., Schledz, M., et al. (1997). Transgenic rice (Oryza sativa) endosperm expressing daffodil (Narcissus pseudonarcissus) phytoene synthase accumulates phytoene, a key intermediate of provitamin A biosynthesis. Plant J. 11, 1071-1078. doi: 10.1046/j.1365-313X.1997.11051071.x

Cahoon, E. B., Hall, S. E., Ripp, K. G., Ganzke, T. S., Hitz, W. D., and Coughlan, S. J. (2003). Metabolic redesign of vitamin E biosynthesis in plants for tocotrienol production and increased antioxidant content. Nat. Biotechnol. 21, 1082-1087. doi: $10.1038 / \mathrm{nbt} 853$

Cercamondi, C. I., Egli, I. M., Mitchikpe, E., Tossou, F., Zeder, C., Hounhouigan, J. D., et al. (2013). Total iron absorption by young women from iron-biofortified pearl millet composite meals is double that from regular millet meals but less than that from post-harvest iron-fortified millet meals. J. Nutr. 143, 1376-1382. doi: 10.3945/jn.113.176826

Chaparro-Giraldo, A., Barata, R., Chabregas, S., Azevedo, R., and Silva-Filho, M. (2000). Soybean leghemoglobin targeted to potato chloroplasts influences growth and development of transgenic plants. Plant Cell Rep. 19, 961-965. doi: 10.1007/s002990000254

Cheema, K. K., Bains, N. S., Mangat, G. S., Das, A., Vikal, Y., Brar, D. S., et al. (2008). Development of high yielding IR64× Oryza rufipogon (Griff.) introgression lines and identification of introgressed alien chromosome segments using SSR markers. Euphytica 160, 401-409. doi: $10.1007 / \mathrm{s} 10681-007-9560-\mathrm{x}$

Chen, H., and Xiong, L. (2009). Enhancement of vitamin B6 levels in seeds through metabolic engineering. Plant Biotechnol. J. 7, 673-681. doi: 10.1111/j.1467-7652.2009.00433.x

Chen, R., Xue, G., Chen, P., Yao, B., Yang, W., Ma, Q., et al. (2008). Transgenic maize plants expressing a fungal phytase gene. Transgenic Res. 17, 633-643. doi: 10.1007/s11248-007-9138-3

Collard, B. C., and Mackill, D. J. (2008). Marker-assisted selection: an approach for precision plant breeding in the twenty-first century. Philos. Trans. R. Soc. Lond. Biol. Sci. 363, 557-572. doi: 10.1098/rstb.2007.2170

Cong, L., Wang, C., Chen, L., Liu, H., Yang, G., and He, G. (2009). Expression of phytoene synthase 1 and carotene desaturase crtI genes result in an increase in the total carotenoids content in transgenic elite wheat (Triticum aestivum L.). J. Agric. Food Chem. 57, 8652-8660. doi: 10.1021/jf90 12218

Connorton, J. M., Jones, E. R., Rodríguez-Ramiro, I., Fairweather-Tait, S., Uauy, C., and Balk, J. (2017). Wheat vacuolar iron transporter TaVIT2 transports Fe and $\mathrm{Mn}$ and is effective for biofortification. Plant Physiol. 174, 2434-2444. doi: $10.1104 /$ pp.17.00672

Cunningham F. Jr., and Gantt, E. (1998). Genes and enzymes of carotenoid biosynthesis in plants. Annu. Rev. Plant Biol. 49, 557-583. doi: 10.1146/annurev.arplant.49.1.557

Curie, C., Cassin, G., Counch, D., Divol, F., Higuchi, K., Le Jean, M., et al. (2009). Metal movement within the plant: contribution of nictotianamine and yellow stripe 1-like transporters. Ann. Bot. 103, 1-11. doi: 10.1093/aob/mcn207

Curtin, S. J., Xiong, Y., Michno, J. M., Campbell, B. W., Stec, A. O., Cermak, T., et al. (2018). CRISPR/Cas9 and TALENs generate heritable mutations for genes involved in small RNA processing of Glycine max and Medicago truncatula. Plant Biotechnol. J. 16, 1125-1137. doi: 10.1111/pbi.12857

Dary, O., and Hainsworth, M. (2008). The Food Fortification Formulator: Technical Determination of Fortification Levels and Standards for Mass Fortification. (Washington, DC: A2Z: The USAID Micronutrient Project/Academy for Educational Development).
De Valença, A. W., Bake, A., Brouwer, I. D., and Giller, K. E. (2017). Agronomic biofortification of crops to fight hidden hunger in sub-Saharan Africa. Glob. Food Secu. 12, 8-14. doi: 10.1016/j.gfs.2016.12.001

Deepa, J., Karthikeyan, R., Gothandapani, S., Shilpha, J., and Gayatri, V., (2018). CRISPR for Crop Improvement: an update review. Front. Plant. Sci. 9:985.

Dela-Garza, R. D., Quinlivan, E. P., Klaus, S. M., Basset, G. J., Gregory, J. F., and Hanson, A. D. (2004). Folate biofortification in tomatoes by engineering the pteridine branch of folate synthesis. Proc. Natl. Acad. Sci. U.S.A. 101, 13720-13725. doi: 10.1073/pnas.0404208101

Delange, F. (1994). The disorders induced by iodine deficiency. Thyroid 4, 107-128. doi: 10.1089/thy.1994.4.107

De-Regil, L. M., Suchdev, P. S., Vist, G. E., Walleser, S., and Peña-Rosas, J. P. (2013). Home fortification of foods with multiple micronutrient powders for health and nutrition in children under two years of age. Evid Based Child Heal. 8, 112-201. doi: 10.1002/ebch.1895

Diretto, G., Tavazza, R., Welsch, R., Pizzichini, D., Mourgues, F., Papacchioli, V., et al. (2006). Metabolic engineering of potato tuber carotenoids through tuber-specific silencing of lycopene epsilon cyclase. BMC Plant Biol. 6:13. doi: 10.1186/1471-2229-6-13

Diretto, G., Welsch, R., Tavazza, R., Mourgues, F., Pizzichini, D., Beyer, P., et al. (2007). Silencing of beta-carotene hydroxylase increases total carotenoid and beta-carotene levels in potato tubers. BMC Plant Biol. 7:11. doi: 10.1186/1471-2229-7-11

Dolde, D., and Wang, T. (2011). Oxidation of crude corn oil with and without elevated tocotrienols. J. Am. Oil Chem. Soc. 88, 1367-1372. doi: 10.1007/s11746-011-1805-0

Dong, O. X., Yu, S., Jain, R., Zhang, N., Duong, P. Q., Butler, C., et al. (2020). Marker-free carotenoid-enriched rice generated through targeted gene insertion using CRISPR-Cas9. Nat. Commun. 11:1178. doi: 10.1038/s41467-020-14981-y

Dosman, C., Witmans, M., and Zwaigenbaum, L. (2012). Iron's role in paediatric restless legs syndrome-a review. Paediatr Child Health. 17, 193-197. doi: $10.1093 / \mathrm{pch} / 17.4 .193$

Douchkov, D., Gryczka, C., Stephan, U., Hell, R., and Bäumlein, H. (2005). Ectopic expression of nicotianamine synthase genes results in improved iron accumulation and increased nickel tolerance in transgenic tobacco. Plant. Cell Environ. 28, 365-374. doi: 10.1111/j.1365-3040.2005.01273.x

Drakakaki, G., Christou, P., and Stoger, E. (2000). Constitutive expression of soybean ferritin cDNA intransgenic wheat and rice results in increased iron levels in vegetative tissues but not in seeds. Transgenic Res. 9, 445-452. doi: 10.1023/A:1026534009483

Drakakaki, G., Marcel, S., Glahn, R. P., Lund, E. K., Pariagh, S., Fischer, R., et al. (2005). Endosperm-specific co-expression of recombinant soybean ferritin and Aspergillus phytase in maize results in significant increases in the levels of bioavailable iron. Plant Mol. Biol. 59, 869-880. doi: 10.1007/s11103-005-1537-3

Ducreux, L. J., Morris, W. L., Hedley, P. E., Shepherd, T., Davies, H. V., Millam, S., et al. (2004). Metabolic engineering of high carotenoid potato tubers containing enhanced levels of $\beta$-carotene and lutein. J. Exp. Bot. 56, 81-89. doi: 10.1093/jxb/eri016

Endo, A., Saika, H., Takemura, M., Misawa, N., and Tok, S. (2019). A novel approach to carotenoid accumulation in rice callus by mimicking the cauliflower orange mutation via genome editing. Rice 12:81. doi: $10.1186 /$ s12284-019-0345-3

Evans, G. (1986). Zinc and its deficiency diseases. Clin. Physiol. Biochem. 4, 94-98. Fitzpatrick, T. B., Basset, G. J., Borel, P., Carrari, F., Della, P. D., Fraser, P. D., et al. (2012). Vitamin deficiencies in humans: can plant science help? Plant Cell 24, 395-414. doi: 10.1105/tpc.111.093120

Frassinetti, S., Bronzetti, G. L., Caltavuturo, L., Cini, M., and Della Croce, C. (2006). The role of zinc in life: a review. J. Environ. Pathol. Toxicol. Oncol. 25, 597-610. doi: 10.1615/JEnvironPatholToxicolOncol.v25.i3.40

Gao, X. R., Wang, G. K., Su, Q., Wang, Y., and An, L. J. (2007). Phytase expression in transgenic soybeans: stable transformation with a vector-less construct. Biotechnol. Lett. 29, 1781-1787. doi: 10.1007/s10529-007-9439-x

Garg, M., Sharma, N., Sharma, S., Kapoor, P., Kumar, A., Chunduri, V., et al. (2018). Biofortified crops generated by breeding, agronomy, and transgenic approaches are improving lives of millions of people around the world. Front. Nutr. 5:12. doi: 10.3389/fnut.2018.00012 
Gibson, R. S. (2007). The role of diet-and host-related factors in nutrient bioavailability and thus in nutrient-based dietary requirement estimates. Food Nutr. Bull. 28, 77-100. doi: 10.1177/15648265070281S108

Gibson, R. S., Bailey, K. B., Gibbs, M., and Ferguson, E. L. (2010). A review of phytate, iron, zinc, and calcium concentrations in plant-based complementary foods used in low-income countries and implications for bioavailability. Food Nutr. Bull. 31, S134-S146. doi: 10.1177/15648265100312S206

Gillespie, S., Hodge, J., Yosef, S., and Pandya-Lorch, R. (2016). Nourishing Millions: Stories of Change in Nutrition. (Washington, DC: International Food Policy Research Institute (IFPRI)).

Goicoechea, N., and Antolín, M. C. (2017). Increased nutritional value in food crops. Microb. Biotechnol.10, 1004-1007. doi: 10.1111/1751-7915.12764

Gonzali, S., Kiferle, C., and Perata, P. (2017). Iodine biofortification of crops: agronomic biofortification, metabolic engineering and iodine bioavailability. Curr. Opin. Biotechnol.44:16-26 doi: 10.1016/j.copbio.2016.10.004

Goto, F., and Yoshihara, T. (2001). Improvement of micronutrient contents by genetic engineering development of high iron content crops. Plant Biotechnol. 18, 7-15. doi: 10.5511/plantbiotechnology.18.7

Graham, R. D., Welch, R. M., and Bouis, H. E. (2001). Addressing micronutrient malnutrition through enhancing the nutritional quality of staple foods: principles, perspectives and knowledge gaps. Advan. Agron. 70, 77-142 doi: 10.1016/S0065-2113(01)70004-1

Greer, M. A., Grim, Y., and Studer, H. (1968). Qualitative changes in the secretion of thyroid hormones induced by iodine deficiency. Endocrinology 83, 1193-1198. doi: 10.1210/endo-83-6-1193

Gropper, S., Smith, J., and Groff, J. (2005). Advanced Nutrition and Human Metabolism. Boston, MA: Wadsworth/Cengage Learning.

Halka, M., Smolen, S., Czernicka, M., Klimek-Chodacka, M., Pitala, J., and Tutaj, K. (2019). Iodine biofortification through expression of HMT, SAMT and S3H genes in Solanum lycopersicum L. Plant Physiol. Biochem. 144, 35-48. doi: 10.1016/j.plaphy.2019.09.028

Hallberg, L. (1981). Bioavailability of dietary iron in man. Annu. Rev. Nutr. 1, 123-147. doi: 10.1146/annurev.nu.01.070181.001011

Hallberg, L., and Hulthen, L. (2000). Prediction of dietary iron absorption: an algorithm for calculating absorption and bioavailability of dietary iron. Am. J. Clin. Nutr. 71, 1147-1160. doi: 10.1093/ajcn/71.5.1147

Hurrell, R. F. (1997). Preventing iron deficiency through food fortification. Nutr. Rev. 55, 210-222. doi: 10.1111/j.1753-4887.1997.tb01608.x

Iqbal, T., Lewis, K., and Cooper, B. (1994). Phytase activity in the human and rat small intestine. Gut 35, 1233-1236. doi: 10.1136/gut.35.9.1233

Ishimaru, Y., Masuda, H., Bashir, K., Inoue, H., Tsukamoto, T., Takahashi, M., et al. (2010). Rice metal-nicotianamine transporter, OsYSL2, is required for the long-distance transport of iron and manganese. Plant J. 62, 379-390. doi: 10.1111/j.1365-313X.2010.04158.x

Itai, R. N., Ogo, Y., Kobayashi, T., Nakanishi, H., and Nishizawa, N. K. (2013). Rice genes involved in phytosiderophore biosynthesis are synchronously regulated during the early stages of iron deficiency in roots. Rice 6:16. doi: 10.1186/1939-8433-6-16

Itoh, N., Toda, H., Matsuda, M., Negishi, T., Taniguchi, T., and Ohsawa, N. (2009). Involvement of S-adenosylmethionine-dependent halide/thiol methyltransferase (HTMT) in methyl halide emissions from agricultural plants: isolation and characterization of an HTMT-coding gene from Raphanus sativus (daikon radish). BMC Plant Biol. 9:116. doi: 10.1186/1471-2229-9-116

Jaganathan, D., Ramasamy, K., Sellamuthu, G., Jayabalan, S., and Venkataraman, G. (2018). CRISPR for crop improvement: an update review. Front. Plant Sci. 9, 971-985. doi: 10.3389/fpls.2018.00985

Jha, A. B., and Warkentin, T. D. (2020). Biofortification of pulse crops: status and future perspectives. Plants 9:73. doi: 10.3390/plants9010073

Ji, J., Zhang, C., Sun, Z., Wang, L., Duanmu, D., and Fan, Q. (2019). Genome editing in cowpea Vigna unguiculata using CRISPR-Cas9. Int. J. Mol. Sci. 20, 2471. doi: 10.3390/ijms20102471

Jimenez, K., Kulnigg-Dabsch, S., and Gasche, C. (2015). Management of iron deficiency anemia. Gastroenterol. Hepatol. 11, 241-250. Available online at: https://www.ncbi.nlm.nih.gov/pubmed/27099596

Johnson, A. A., Kyriacou, B., Callahan, D. L., Carruthers, L., Stangoulis, J., Katona, P., et al. (2008). The interaction between nutrition and infection. Clin. Infect. Dis. 46, 1582-1588. doi: 10.1086/587658
Kim, S., Takahashi, M., Higuchi, K., Tsunoda, K., Nakanishi, H., Yoshimura, E., et al. (2005). Increased nicotianamine biosynthesis confers enhanced tolerance of high levels of metals, in particular nickel, to plants. Plant Cell Physiol. 46, 1809-1818. doi: 10.1093/pcp/pci196

Kim, S. A., Punshon, T., Lanzirotti, A., Li, L., Alonso, J. M., Ecker, J. R., et al. (2006). Localization of iron in Arabidopsis seed requires the vacuolar membrane transporter VIT1. Science 314, 1295-1298. doi: 10.1126/science.1132563

Kobayashi, T., Itai, R. N., Ogo, Y., Kakei, Y., Nakanishi, H., Takahashi, M., et al. (2009). The rice transcription factor IDEF1 is essential for the early response to iron deficiency and induces vegetative expression of late embryogenesis abundant genes. Plant J. 60:948-961. doi: 10.1111/j.1365-313X.2009.04015.x

Kobayashi, T., Ogo, Y., Aung, M. S., Nozoye, T., Itai, R. N., Nakanishi, H., et al. (2010). The spatial expression and regulation of transcription factors IDEF1 and IDEF2. Ann. Bot. 105,1109-1117. doi: 10.1093/aob/mcq002

Kohli, A., González-Melendi, P., Abranches, R., Capell, T., Stoger, E., and Christou, P. (2006). The quest to understand the basis and mechanisms that control expression of introduced transgenes in crop plants. Plant Signal. Behav. 1, 185-195. doi: 10.4161/psb.1.4.3195

Koike, S., Inoue, H., Mizuno, D., Takahashi, M., Nakanishi, H., Mori, S., et al. (2004). OsYSL2 is a rice metal-nicotianamine transporter that is regulated by iron and expressed in the phloem. Plant J. 39, 415-424. doi: 10.1111/j.1365-313X.2004.02146.x

Kumssa, D. B., Joy, E. J., Ander, E. L., Watts, M. J., Young, S. D., Walker, S., et al. (2015). Dietary calcium and zinc deficiency risks are decreasing but remain prevalent. Sci. Rep. 5:10974. doi: 10.1038/srep10974

Landini, M., Gonzali, S., Kiferle, C., Tonacchera, M., Agretti, P., Dimida, A., et al. (2012). Metabolic engineering of the iodine content in Arabidopsis. Sci. Rep. 2:338. doi: $10.1038 /$ srep00338

Lanquar, V., Lelièvre, F., Bolte, S., Hamès, C., Alcon, C., Neumann, D., et al. (2005). Mobilization of vacuolar iron by AtNRAMP3 and AtNRAMP4 is essential for seed germination on low iron. EMBO J. 24, 4041-4051. doi: 10.1038/sj.emboj.7600864

Layrisse, M., Martínez-Torres, C., Leets, I., Taylor, P., and Ramírez, J. (1984). Effect of histidine, cysteine, glutathione or beef on iron absorption in humans. J. Nutr. 114, 217-223. doi: 10.1093/jn/114.1.217

Lee, H. (2017). Transgenic pro-vitamin a biofortified crops for improving vitamin A deficiency and their challenges. Open Agric. J. 11, 11-23. doi: 10.2174/1874331501711010011

Lee, S., Kim, Y. Y., Lee, Y., and An, G. (2007). Rice P1B-type heavy-metal ATPase, OsHMA9, is a metal efflux protein. Plant Physiol. 145, 831-842. doi: $10.1104 / \mathrm{pp} .107 .102236$

Lee, S., Persson, D. P., Hansen, T. H., Husted, S., Schjoerring, J. K., Kim, Y. S., et al. (2011). Bio-available zinc in rice seeds is increased by activation tagging of nicotianamine synthase. Plant Biotechnol. J. 9, 865-873. doi: 10.1111/j.1467-7652.2011.00606.x

Lehtovaara, P., and Ellfolk, N. (1975). Purification and properties of Phaseolus vulgaris leghemoglobin. Acta. Chem. Scand. B 29, 56-60. doi: 10.3891/acta.chem.scand.29b-0056

Li, D., Xu, X., Hu, X., Liu, Q., Wang, Z., Zhang, H., et al. (2015). Genomewide analysis and heavy metal-induced expression profiling of the HMA gene family in populus trichocarpa. Front. Plant Sci. 6:1149. doi: 10.3389/fpls.2015. 01149

Li, L., Yang, Y., Xu, Q., Owsiany, K., Welsch, R., Chitchumroonchokchai, C., et al. (2012). The Or gene enhances carotenoid accumulation and stability during post-harvest storage of potato tubers. Mol. Plant 5, 339-352. doi: $10.1093 / \mathrm{mp} / \mathrm{ssr} 099$

Lonnerdal, B. (2003). Genetically modified plants for improved trace element nutrition. J. Nutr. 133, 1490S-1493S. doi: 10.1093/jn/133.5.1490S

Lucca, P., Hurrell, R., and Potrykus, I. (2001). Approaches to improving the bioavailability and level of iron in rice seeds. J. Sci. Food Agric. 81, 828-834. doi: $10.1002 /$ jsfa.886

Lucca, P., Poletti, S., and Sautter, C. (2006). Genetic engineering approaches to enrich rice with iron and vitamin A. Physiol. Plant. 126, 291-303. doi: 10.1111/j.1399-3054.2006.00609.x

Lyu, D., Backer, R., Subramanian, S., and Smith, D. L. (2020). Phytomicrobiome coordination signals hold potential for climate change-resilient agriculture. Front. Plant Sci. 11:634. doi: 10.3389/fpls.2020.00634 
Maggini, S., Maldonado, P., Cardim, P., Fernandez Newball, C., and Sota Latino, E. (2017). Vitamins C, D and Zinc: synergistic roles in immune function and infections. Vitamin Miner. 6:167. doi: 10.4172/2376-1318.1000167

Maret, W., and Sandstead, H. H. (2006). Zinc requirements and the risks and benefits of zinc supplementation. J. Trace Elem. Med. Biol. 20, 3-18. doi: 10.1016/j.jtemb.2006.01.006

Marschner, P. (2012). Rhizosphere Biology, Marschner's Mineral Nutrition of Higher Plants, $3 r d$ Edn. London: Elsevier.

Masuda, H., Usuda, K., Kobayashi, T., Ishimaru, Y., Kakei, Y., Takahashi, M., et al. (2009). Overexpression of the barley nicotianamine synthase gene HvNAS1 increases iron and zinc concentrations in rice grains. Rice 2, 155-166. doi: 10.1007/s12284-009-9031-1

Miller, J. L. (2013). Iron deficiency anemia: a common and curable disease. Cold Spring Harb. Perspect. Med. 3:7. doi: 10.1101/cshperspect.a011866

Mizuno, D., Higuchi, K., Sakamoto, T., Nakanishi, H., Mori, S., and Nishizawa, N. K. (2003). Three nicotianamine synthase genes isolated from maize are differentially regulated by iron nutritional status. Plant Physiol. 132, 1989-1997. doi: 10.1104/pp.102.019869

Moose, S. P., and Mumm, R. H. (2008). Molecular plant breeding as the foundation for 21st Century crop improvement. Plant Physiol. 147, 969-977. doi: $10.1104 /$ pp.108.118232

Morrissey, J., and Guerinot, M. L. (2009). Iron uptake and transport in plants: the good, the bad, and the ionome. Chem. Rev. 109, 4553-4567. doi: $10.1021 / \mathrm{cr} 900112 \mathrm{r}$

Muthayya, S., Rah, J. H., Sugimoto, J. D., Roos, F. F., Kraemer, K., and Black, R. E. (2013). The global hidden hunger indices and maps: an advocacy tool for action. PLoS ONE 8:e67860. doi: 10.1371/journal.pone.0067860

Naqvi, S., Zhu, C., Farre, G., Ramessar, K., Bassie, L., Breitenbach, J., et al. (2009). Transgenic multivitamin corn through biofortification of endosperm with three vitamins representing three distinct metabolic pathways. Proc. Natl. Acad. Sci. U.S.A. 106, 7762-7767. doi: 10.1073/pnas.0901412106

Nestel, P., Bouis, H. E., Meenakshi, J., and Pfeiffer, W. (2006). Biofortification of staple food crops. J. Nutr. 136, 1064-1067. doi: 10.1093/jn/136.4.1064

Paine, J. A., Shipton, C. A., Chaggar, S., Howells, R. M., Kennedy, M. J., Vernon, G., et al. (2005). Improving the nutritional value of Golden Rice through increased pro-vitamin A content. Nat. Biotechnol. 23, 482-487. doi: 10.1038/nbt1082

Palmgren, M. G., Clemens, S., Williams, L. E., Krämer, U., Borg, S., Schjørring, J. K., et al. (2008). Zinc biofortification of cereals: problems and solutions. Trends Plant Sci. 13, 464-473. doi: 10.1016/j.tplants.2008.06.005

Patil, S. B., Chitgupekar, S. C., and Patil, B. B. (2015). Modern tillage and integrated nutrient management practices for improving soil fertility and productivity of groundnut (Arachis hypogaea L.) under rainfed farming system. Int. Lett. Natl. Sci. 2, 1-12. doi: 10.18052/www.scipress.com/ILNS.29.1

Perez-Massot, E., Banakar, R., Gómez-Galera, S., Zorrilla-López, U., Sanahuja, G., Arjó, G., et al. (2013). The contribution of transgenic plants to better health through improved nutrition: opportunities and constraints. Genes Nutr. 8, 29-41. doi: 10.1007/s12263-012-0315-5

Ramesh, S. A., Choimes, S., and Schachtman, D. P. (2004). Over-expression of an Arabidopsis zinc transporter in Hordeum vulgare increases short-term zinc uptake after zinc deprivation and seed zinc content. Plant Mol. Biol. 54, 373-385. doi: 10.1023/B:PLAN.0000036370.70912.34

Raschke, M., Boycheva, S., Crèvecoeur, M., Nunes-Nesi, A., Witt, S., Fernie, A. R., et al. (2011). Enhanced levels of vitamin B6 increase aerial organ size and positively affect stress tolerance in Arabidopsis. Plant J. 66, 414-432. doi: 10.1111/j.1365-313X.2011.04499.x

Ricachenevsky, F. K., Menguer, P. K., Sperotto, R. A., Williams, L. E., and Fett, J. P. (2013). Roles of plant metal tolerance proteins (MTP) in metal storage and potential use in biofortification strategies. Front. Plant Sci. 4:144. doi: 10.3389/fpls.2013.00144

Ricroch, A., Clairand, P., and Harwood, W. (2017). Use of CRISPR systems in plant genome editing: toward new opportunities in agriculture. Emerg. Top Life Sci. 1, 169-182. doi: 10.1042/ETLS20170085

Rizvi, S., Raza, S. T., Ahmed, F., Ahmad, A., Abbas, S., and Mahdi, F. (2014). The role of vitamin E in human health and some diseases. Sultan Qaboos Univ. Med. J. 14, e157-e165.

Rogers, E. E., and Guerinot, M. L. (2002). FRD3, a member of the multidrug and toxin efflux family, controls iron deficiency responses in Arabidopsis. Plant Cell. 14, 1787-1799. doi: 10.1105/tpc.001495
Sahu, A. (2017). Acquisition Related Genes Involved in Early stage iron deficiency response in foxtail millet (Setaria italica). (Ph.D. dissertation/master's thesis). College of Agriculture. Indira Gandhi Krishi Vishwavidhyalaya, Raipur.

Schneeman, B. O. (2001). Linking agricultural production and human nutrition. J. Sci. Food Agric. 81, 3-9. doi: 10.1002/1097-0010(20010101)81:1\&lt;3::AID-JSFA743\&gt;3.0.CO;2-Q

Scholes, J., Endacott, R., Biro, M., Bulle, B., Cooper, S., and Miles, M. (2012). Clinical decision-making: midwifery students' recognition of, and response to, post-partum haemorrhage in the simulation environment. BMC Pregnancy Childbirth 12:19. doi: 10.1186/1471-2393-12-19

Schroder, I., Johnson, E., and de Vries, S. (2003). Microbial ferric iron reductases. FEMS Microbiol. Rev. 27, 427-447. doi: 10.1016/S0168-6445(03)00043-3

Schroeder, J. I., Delhaize, E., Frommer, W. B., Guerinot, M. L., Harrison, M. J., and Herrera-Estrella, L. (2013). Using membrane transporters to improve crops for sustainable food production. Nature 497, 60-67. doi: 10.1038/nature 11909

Schwartz, M. S., Benci, J. L., Selote, D. S., Sharma, A. K., Chen, A. G., Dang, H., et al. (2010). Detoxification of multiple heavy metals by a half-molecule ABC transporter, HMT-1, and coelomocytes of Caenorhabditis elegans. PLoS ONE. 5:9564. doi: 10.1371/journal.pone.0009564

Sedeek, K. E. M., Mahas, A., and Mahfouz, M. (2019). Plant genome engineering for targeted improvement of crop traits. Front. Plant Sci. 10:114. doi: 10.3389/fpls.2019.00114

Shewmaker, C. K., Sheehy, J. A., Daley, M., Colburn, S., and Ke, D. Y. (1999). Seed-specific overexpression of phytoene synthase: increase in carotenoids and other metabolic effects. Plant J. 20, 401-412. doi: 10.1046/j.1365-313x.1999. 00611.x

Simpson, J. L., Bailey, L. B., Pietrzik, K., Shane, B., and Holzgreve, W. (2011). Micronutrients and women of reproductive potential: required dietary intake and consequences of dietary deficiency or excess. J. Matern. Neonatal Med. 24, 1-24. doi: 10.3109/14767051003678226

Singh, S. P., Keller, B., Gruissem, W., and Bhullar, N. K. (2017). Rice nicotianamine synthase 2 expression improves dietary iron and zinc levels in wheat. Theor. Appl. Genet. 130, 283-292. doi: 10.1007/s00122-016-2808-x

Sinha, P., Davis, J., Saag, L., Wanke, C., Salgame, P., Mesick, J., et al. (2019). Undernutrition and tuberculosis: public health implications. J. Infect. Dis. 219, 1356-1363, doi: 10.1093/infdis/jiy675

Smethurst, P., and Comerford, N. (1993). Simulating nutrient uptake by single or competing and contrasting root systems. Soil Sci. Soc. Am. J. 57, 1361-1367. doi: 10.2136/sssaj1993.03615995005700050033x

Storozhenko, S., De Brouwer, V., Volckaert, M., Navarrete, O., Blancquaert, D., Zhang, G. F., et al. (2007). Folate fortification of rice by metabolic engineering. Nat. Biotechnol. 25, 1277-1279. doi: 10.1038/nbt1351

Suzuki, Y. A., Kelleher, S. L., Yalda, D., Wu, L., Huang, J., Huang, N., et al. (2003). Expression, characterization, and biologic activity of recombinant human lactoferrin in rice. J. Pediatr. Gastroenterol. Nutr. 36, 190-199. doi: 10.1097/00005176-200302000-00007

Suzuki, Y. A., Shin, K., and Lönnerdal, B. (2001). Molecular cloning and functional expression of a human intestinal lactoferrin receptor. Biochemistry 40, 15771-15779. doi: 10.1021/bi0155899

Takahashi, M., Terada, Y., Nakai, I., Nakanishi, H., Yoshimura, E., and Mori, S. (2003). Role of nicotianamine in the intracellular delivery of metals and plant reproductive development. Plant Cell. 15, 1263-1280. doi: 10.1105/tpc.010256

Takahashi, R., Bashir, K., Ishimaru, Y., Nishizawa, N. K., and Nakanishi, H. (2012). The role of heavy-metal ATPases, HMAs, in zinc and cadmium transport in rice. Plant Signal Behav. 7, 1605-1607. doi: 10.4161/psb.22454

Tanaka, H., Yabuta, Y., Tamoi, M., Tanabe, N., and Shigeoka, S. (2015). Generation of transgenic tobacco plants with enhanced tocotrienol levels through the ectopic expression of rice homogentisate geranylgeranyl transferase. Plant Biotechnol. 32, 233-238. doi: 10.5511/plantbiotechnology.15.0702a

Theil, E., Burton, J., and Beard, J. (1997). A sustainable solution for dietary iron deficiency through plant biotechnology and breeding to increase seed ferritin control. Eur. J. Clin. Nutr. 51, S28-31.

Theil, E. C. (2011). Iron homeostasis and nutritional iron deficiency. J. Nutr. 141, 724S-728S. doi: 10.3945/jn.110.127639

Vansuyt, G., Mench, M., and Briat, J. F. (2000). Soil-dependent variability of leaf iron accumulation in transgenic tobacco overexpressing ferritin. Plant Physiol. Biochem. 38, 499-506. doi: 10.1016/S0981-9428(00)00763-4 
Vasconcelos, M., Datta, K., Oliva, N., Khalekuzzaman, M., Torrizo, L., Krishnan, S., et al. (2003). Enhanced iron and zinc accumulation in transgenic rice with the ferritin gene. Plant Sci. 164, 371-378. doi: 10.1016/S0168-9452(02) 00421-1

Vos, T., Flaxman, A. D., Naghavi, M., Lozano, R., Michaud, C., Ezzati, M., et al. (2012). Years lived with disability (YLDs) for 1160 sequelae of 289 diseases and injuries 1990-2010, a systematic analysis for the global burden of disease study 2010. Lancet 380, 2163-2196. doi: 10.1016/S0140-6736(12) 61729-2

Wang, C., Zeng, J., Li, Y., Hu, W., Chen, L., Miao, Y., et al. (2014). Enrichment of provitamin A content in wheat (Triticum aestivum L.) by introduction of the bacterial carotenoid biosynthetic genes CrtB and CrtI. J. Exp. Bot. 65, 2545-2556. doi: 10.1093/jxb/eru138

Welch, R. M. (2002). Breeding strategies for biofortified staple plant foods to reduce micronutrient malnutrition globally. J. Nutr. 132, 495S-499S. doi: $10.1093 / \mathrm{jn} / 132.3 .495 \mathrm{~S}$

Welch, R. M., and Graham, R. D. (2004). Breeding for micronutrients in staple food crops from a human nutrition perspective. J. Exp. Bot. 55, 353-364. doi: $10.1093 /$ jxb/erh064

Welsch, R., Arango, J., Bär, C., Salazar, B., Al-Babili, S., Beltrán, J., et al. (2010). Provitamin A accumulation in cassava (Manihot esculenta) roots driven by a single nucleotide polymorphism in a phytoene synthase gene. Plant Cell. 22, 3348-3356. doi: 10.1105/tpc.110.077560

Welsch, R., Maass, D., Voegel, T., DellaPenna, D., and Beyer, P. (2007). Transcription factor RAP2. 2 and its interacting partner SINAT2, stable elements in the carotenogenesis of Arabidopsis leaves. Plant Physiol. 145, 1073-1085. doi: 10.1104/pp.107.104828

White, P. J., and Broadley, M. R. (2005). Biofortifying crops with essential mineral elements. Trends Plant Sci. 10, 586-593. doi: 10.1016/j.tplants.2005.10.001

Williams, M., and Yanai, R. D. (1996). Multi-dimensional sensitivity analysis and ecological implications of a nutrient uptake model. Plant Soil 180, 311-324. doi: 10.1007/BF00015315

Wirth, J., Poletti, S., Aeschlimann, B., Yakandawala, N., Drosse, B., Osorio, S., et al. (2009). Rice endosperm iron biofortification by targeted and synergistic action of nicotianamine synthase and ferritin. Plant Biotechnol. J. 7, 631-644. doi: 10.1111/j.1467-7652.2009.00430.x

Wong, J., Lambert, R., Wurtzel, E., and Rocheford, T. (2004). QTL and candidate genes phytoene synthase and carotene desaturase associated with the accumulation of carotenoids in maize. Theor. Appl. Genet. 108, 349-359. doi: 10.1007/s00122-003-1436-4

Wood, S. A., and Baudron, F. (2018). Soil organic matter underlies crop nutritional quality and productivity in smallholder agriculture. Agr. Ecosyst. Environ. 266, 100-108. doi: 10.1016/j.agee.2018.07.025

Xiaoyan, S., Yan, Z., and Shubin, W. (2012). Improvement Fe content of wheat (Triticum aestivum) grain by soybean ferritin expression cassette without vector backbone sequence. J. Agric. Food Biochem. 20,
766-773. Available online at: https://www.semanticscholar.org/ paper/Improvement-Fe-Content-of-Wheat(Triticum-aestivum)-Xiao/ 74c0480abe93478866cc155188e64407f1ff68e6

Yang, W., Cahoon, R. E., Hunter, S. C., Zhang, C., Han, J., Borgschulte, T., et al. (2011). Vitamin E biosynthesis: functional characterization of the monocot homogentisate geranylgeranyl transferase. Plant J. 65, 206-217. doi: 10.1111/j.1365-313X.2010.04417.x

Ye, X., Al-Babili, S., Klöti, A., Zhang, J., Lucca, P., Beyer, P., et al. (2000). Engineering the provitamin A ( $\beta$-carotene) biosynthetic pathway into (carotenoid-free) rice endosperm. Science 287, 303-305. doi: $10.1126 /$ science.287.5451.303

Yip, R. (1994). Iron deficiency: contemporary scientific issues and international programmatic approaches. J. Nutr. 124, 1479-1490. doi: 10.1093/jn/124.suppl_8.1479S

Zhang, F., Shen, J., Zhang, J., Zuo, Y., Li, L., and Chen, X. (2010). Rhizosphere processes and management for improving nutrient use efficiency and crop productivity: implications for China. Advn. Agron. 107, 1-32. doi: 10.1016/S0065-2113(10)07001-X

Zhou, J. R., and Erdman J. W. Jr. (1995). Phytic acid in health and disease. Crit. Rev. Food Sci. Nutr. 35, 495-508. doi: 10.1080/10408399509527712

Zhu, C., Naqvi, S., Breitenbach, J., Sandmann, G., Christou, P., and Capell, T. (2008). Combinatorial genetic transformation generates a library of metabolic phenotypes for the carotenoid pathway in maize. Proc. Natl. Acad. Sci. U.S.A. 105, 18232-18237. doi: 10.1073/pnas.08097 37105

Zimmermann, M. B., Aeberli, I., Torresani, T., and Burgi, H. (2005). Increasing the iodine concentration in the Swiss iodized salt program markedly improved iodine status in pregnant women and children: a 5-y prospective national study. Am. J. Clin. Nutr. 82, 388-392. doi: 10.1093/ajcn/82.2.388

Zimmermann, M. B., and Boelaert, K. (2015). Iodine deficiency and thyroid disorders. Lancet Diabetes Endocrinol. 3, 286-295. doi: 10.1016/S2213-8587(14)70225-6

Zimmermann, M. B., and Hurrell, R. F. (2002). Improving iron, zinc and vitamin A nutrition through plant biotechnology. Curr. Opin. Biotechnol. 13, 142-145. doi: 10.1016/S0958-1669(02)00304-X

Conflict of Interest: The authors declare that the research was conducted in the absence of any commercial or financial relationships that could be construed as a potential conflict of interest.

Copyright (c) 2020 Malik and Maqbool. This is an open-access article distributed under the terms of the Creative Commons Attribution License (CC BY). The use, distribution or reproduction in other forums is permitted, provided the original author(s) and the copyright owner(s) are credited and that the original publication in this journal is cited, in accordance with accepted academic practice. No use, distribution or reproduction is permitted which does not comply with these terms. 